\title{
Government Preferences and SEC Enforcement
}

\section{Citation}

Heese, Jonas. "Government Preferences and SEC Enforcement." Harvard Business School Working Paper, No. 15-054, December 2014. (Revised April 2015.)

\section{Permanent link}

http://nrs.harvard.edu/urn-3:HUL.InstRepos:13596846

\section{Terms of Use}

This article was downloaded from Harvard University's DASH repository, and is made available under the terms and conditions applicable to Open Access Policy Articles, as set forth at http:// nrs.harvard.edu/urn-3:HUL.InstRepos:dash.current.terms-of-use\#OAP

\section{Share Your Story}

The Harvard community has made this article openly available.

Please share how this access benefits you. Submit a story.

Accessibility 
H A R V A R D

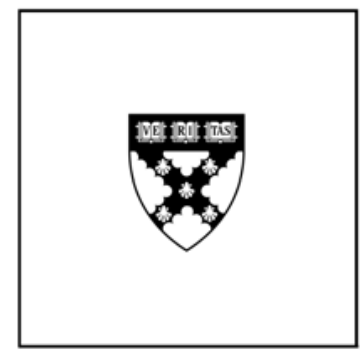

\title{
Government Preferences and SEC Enforcement
}

\author{
Jonas Heese
}

\section{Working Paper}

\section{5-054}

April 13, 2015 


\title{
Government preferences and SEC enforcement
}

\author{
Jonas Heese \\ Accounting \& Management Unit \\ Harvard Business School \\ Morgan Hall 397 \\ Boston, MA 02163 \\ USA \\ phone: +16174952827 \\ fax: +1 6174967387 \\ email: jheese@hbs.edu
}

April 2015

\begin{abstract}
Acknowledgements: I thank my dissertation chairs Ranjani Krishnan and Frank Moers for their ongoing, invaluable advice, and support. I also thank Vishal Baloria, Elina Heese, Mo Khan, Robert Khuzami (former Director of SEC's Division of Enforcement), Phil Quinn, Karthik Ramanna, Eugene Soltes, Patrick Vorst, and workshop participants at Aalto University, Bocconi University, Erasmus University, Frankfurt School of Finance \& Management, Harvard Business School, KU Leuven, London School of Economics and Political Science, Maastricht University, Michigan State University, Nanyang Technological University, Tilburg University, University of Arizona, University of Miami, the 2014 AAA and EAA Annual Meetings, and the 2015 MAS Meeting. I am grateful to Diego Garcia and Oyvind Norli for providing data on geographic locations of firm operations.
\end{abstract}




\title{
Government preferences and SEC enforcement
}

\begin{abstract}
I examine whether political influence by the government as a response to voters' interest in employment conditions is reflected in the enforcement actions of the Securities and Exchange Commission (SEC). I find that large employers are less likely to be subject to an SEC enforcement action, after controlling for firm size, accounting quality, distance to SEC office, and political contributions, among other factors. Next, I show that large employers are less likely to face an SEC enforcement action in presidential election years if they are headquartered in politically important states. I also find that firms that employ a larger proportion of a congressional district's total workforce and are located in districts with high unemployment rates are less likely to be subject to an SEC enforcement action if the incumbent congressman serves on a committee that oversees the SEC. These findings suggest that voters' interests are reflected in SEC enforcement.
\end{abstract}

Keywords: SEC enforcement, government preferences, employment, voters’ interests

JEL classification: D72, G18, M41, M43 
"[...] A decision to charge an entire company may well cause harm to some innocent personsemployees, customers and shareholders. So, the question is whether law enforcement interests are served by charging a company, knowing that the decision may create harm to innocent persons [...]."

Robert Khuzami, former Director of SEC's Division of Enforcement, The Deal 2013

"Some have questioned whether it is appropriate for prosecutors to consider the consequencesdirect and collateral - when they make a decision whether to indict a company. Of course they should; we want their decision to be thoughtful and in the public interest."

Mary Jo White, Chair of the SEC, Speech at NYC Bar Association May 19, 2014

\section{INTRODUCTION}

The Securities and Exchange Commission's (SEC) enforcement actions have been subject to increased scrutiny following the SEC's failure to detect several frauds such as those executed by Bernard Madoff and Sir Allen Stanford (see e.g., Henriques 2009; Waas 2012). A growing literature in accounting examines the reasons for such failure in SEC enforcement by investigating the SEC's choice of enforcement targets. These studies indicate that the resource constraints of the SEC, as well as political pressure arising from firms' political connections on the SEC, affect the agency's choice of enforcement targets (Correia 2014; Kedia and Rajgopal 2011; Yu and $\mathrm{Yu} 2011)$.

While these studies recognize that the SEC and its enforcement actions are subject to political influence, they do not consider that such influence by the president and Congress (“government") may also reflect voters' interests—independent of firms' political connections. ${ }^{1}$ Yet, economists such as Stigler (1971) and Peltzman (1976) have long emphasized that the government influences regulations and regulatory agencies to reflect both voters' and special interests in order to maximize political support. In this paper, I investigate whether the government's influence on the SEC reflects voters' interests.

\footnotetext{
${ }^{1}$ Throughout the paper I use the term "government" when I refer to both the executive, i.e., the president, as well as the legislative, i.e., Congress, branches of the federal government.
} 
One of the main factors that drives voters' political support are employment conditions, which are shown to systematically affect future electoral outcomes (Hibbs 2006; MacRae 1977). To promote these conditions governments of both parties have long supported large employers through, for instance, bailouts, tax favors or subsidies in order to prevent huge job losses or the destabilization of an entire industry (Adams and Brock 1987a, 1987b, 2004).

The SEC's enforcement actions can significantly jeopardize the employment conditions as these actions can have devastating consequences for firms and therefore employment. In particular, sanctions directed by the SEC in combination with negative market reactions result in huge reputational and financial costs for the firm, and can ultimately lead to bankruptcy of the convicted firm (Feroz, Park, and Pastena 1991; Karpoff, Lee, and Martin 2008a, 2008b). ${ }^{2}$ As job losses can be a direct consequence of bankruptcy, SEC enforcement actions not only affect the economic wealth of a firm's shareholders, but also that of a firm's employees.

The government has a range of control devices at its disposal to align the SEC's decisions with government's goals (Weingast 1984). In particular, Congress sets the SEC's budget and oversees the agency, while the president appoints SEC commissioners with the advice and consent of the Senate (SEC 2013a; Weingast 1984). ${ }^{3}$ As the SEC has limited resources, it cannot investigate all firms and consequently has to make choices in its enforcement actions (SEC 2013b). Such choices are influenced by the politically-appointed commissioners as they control

\footnotetext{
${ }^{2}$ For instance, Karpoff et al. (2007) show that about 34 percent of the firms that are subject to an SEC enforcement action file bankruptcy, and over 70 percent of the firms that filed bankruptcy did so during the period of the enforcement action, but only a minority did so during the violation period or in the period between the violation and the enforcement action. Thus, while these findings do not rule out that firms that are subject to an SEC enforcement action might already have been on the verge of bankruptcy, they suggest that such action might trigger a firm's bankruptcy or accelerate the process that leads to a firm's bankruptcy.

${ }^{3}$ Several Congressional Committees are involved in setting the SEC's budget and overseeing the agency. The Senate Banking, Housing and Urban Affairs Committee, and the House Financial Services Committee oversee the SEC. The Senate Commerce Committee oversees securities issues and the House Energy and Commerce Committee oversees accounting issues and the Financial Accounting Standards Board (FASB). The Senate and House Appropriations Committees decide on the SEC's appropriations (Correia 2014; Weingast 1984).
} 
the enforcement process. In particular, the commissioners set the SEC's enforcement priorities, which constrain staff's initial investigations, and authorize every enforcement action, allowing them to overrule staff's enforcement recommendations (SEC 2013b, 2014a). In their decisions, commissioners and senior SEC staff might consider the harm to employees that an enforcement action can create. For instance, Robert Khuzami, the former Director of the SEC's Division of Enforcement, states that the SEC has to ask itself "under what circumstances [it] should indict an entire institution for the misconduct of some number of its employees" as such action may cause harm to innocent employees (Orol 2013). ${ }^{4}$ In line with Khuzami's statement, Mary Jo White, the current Chair of the SEC, argues that prosecutors should consider the direct and collateral consequences such as the harm to employees when they make a decision as to whether to indict a company as their decision should be "thoughtful and in the public interest" (SEC 2014c).

Following the above arguments, I propose that the SEC — as a result of government's efforts to promote employment conditions-considers the potential harm to employees in its enforcement actions and perceives this harm to be higher, the larger a firm's workforce is. Consequently, I investigate whether large employers are less likely to be subject to an SEC enforcement action.

To test my hypothesis, I use a sample of firms, for the time period 1982 to 2012, that have been sanctioned by the SEC for violating Generally Accepted Accounting Principles (GAAP) as reported in Accounting and Auditing Enforcement Releases (AAERs) and all other public firms that did not receive an AAER over this period. I use two different research designs to investigate the relationship between AAERs and large employers. First, I use a regression equation that relates AAERs to firms' number of employees controlling for other confounding variables such

\footnotetext{
${ }^{4}$ According to Khuzami, Arthur Andersen provides a compelling case why an entire institution should not be charged, given that the SEC's and Department of Justice's (DOJ) enforcement efforts drove the firm to bankruptcy and all employees lost their jobs (Orol 2013).
} 
as firm size, accounting quality, distance to SEC office, political contributions, union membership per industry, and other monitors such as analysts following. Second, I form matched pairs using propensity score matching $(\mathrm{PSM}) .^{5}$ In particular, I match firms in the largest employment-size quartile with firms outside this employment-size quartile that do not exhibit any significant differences along all of the aforementioned observable firm characteristics such as firm asset size. Using both research designs, I find evidence that large employers are less likely to be subject to an AAER. These findings are consistent with my hypothesis that government's employment considerations are reflected in SEC enforcement.

These findings, however, might be driven by unobserved correlated omitted firm characteristics of large employers. To rule out this alternative explanation and to test more directly how political influence from the government affects SEC enforcement, I further examine whether variations in the government's sensitivity to voters' interests result in variations in SEC enforcement actions against these firms.

Prior research in political economy especially highlights the role of upcoming elections as a period in which the government is likely to take measures to ensure political support in the upcoming election (Brown and Dinc 2005; Kido, Petacchi, and Weber 2012; Kramer 1971; Ramanna and Roychowdhury 2010). Therefore, I examine SEC enforcement behavior during presidential election years. I argue that government's increased sensitivity to voters' interests during election years results in a more prominent consideration of employment effects by the SEC, leading to even fewer enforcement actions against large employers. I find that the lower likelihood of SEC enforcement actions against large employers is more pronounced in

\footnotetext{
${ }^{5}$ See, for instance, Armstrong et al. (2010) for a recent study in the accounting literature that applies propensity score matching in the context of accounting irregularities.
} 
presidential election years if firms are headquartered in politically important states, i.e., closely contested states with high Electoral College counts.

Research in political economy shows that a congressional district's employment conditions affect political support for members of the House (e.g., Goodman and Kramer 1975). Therefore, I examine SEC enforcement behavior against firms that employ a larger proportion of the total workforce of the district where they are located ("locally large employers"). ${ }^{6}$ A congressman is likely to be especially sensitive to his/her district's employment conditions if the local unemployment rate is higher than in other districts (Gartzke and Wrighton 1998; Kiewiet and McCubbins 1985). Prior studies have also documented that the ability of congressmen to influence SEC enforcement is likely to be higher for congressmen who serve on committees that oversee the SEC (Correia 2014; Weingast 1984). Thus, I examine whether the lower likelihood of SEC enforcement for locally large employers is more pronounced if the district's unemployment rate is high and the incumbent congressman serves on a committee that oversees the SEC. I find support for this hypothesis.

Reduced SEC enforcement against large employers might also be explained by a potentially higher level of accounting quality. Even though I include a firm's F-score as a control variable in all of my earlier tests to control for a firm's accounting quality (Dechow, Ge, Larson, and Sloan 2011), I run several additional tests to investigate whether firms that are large employers have a better accounting quality and consequently fewer SEC enforcement actions. ${ }^{7}$ I use all three specifications of the F-score as developed by Dechow et al. (2011), discretionary accruals based

\footnotetext{
${ }^{6}$ To measure firms' share of a district's total employment, I obtain data from Garcia and Norli (2012), who developed a method to allocate firms' operations to their headquarter state based on the number of times the headquarter state name is mentioned in firms' $10-\mathrm{Ks}$ relative to all other state names.

${ }^{7}$ The F-score developed by Dechow et al. (2011) is a scaled probability that can be used as a red flag of the likelihood of earnings misstatement. Dechow et al. (2011) developed the F-score by investigating financial characteristics of firms that have been subject to an AAER.
} 
on the modified Jones model as in Dechow et al. (2011) and the Dechow and Dichev (2002) model, and the incidence of accounting restatements as proxies for a firm's accounting quality. I find consistent evidence that large employers have lower accounting quality than their smaller peers, suggesting that the reduced likelihood of SEC enforcement against large employers cannot be explained by these firms having higher accounting quality.

Furthermore, I investigate whether large employers receive fewer comment letters from the SEC. As comment letters are a potential trigger event for an SEC enforcement action, examining whether large employers receive fewer of these letters can provide indications at which stage of the SEC enforcement process the SEC adjusts its enforcement actions in accordance with the government's preference for employment. ${ }^{8}$ I find that large employers receive fewer comment letters after controlling for firm size, firm performance, accounting quality, and political contributions, among other factors. These findings suggest that the SEC allocates fewer resources to reviews of significant employers, which might lead to fewer trigger events and consequently enforcement actions against these firms.

Finally, I run several sensitivity tests to address potential concerns of my research design. First, instead of comparing an AAER firm to the average non-AAER firm, I examine the incidence of AAERs in a sample of firms subject to class action lawsuits. Such firms potentially engaged in accounting irregularities, and the class-action lawyers have no reason to consider employment consequences of their actions. In this sample, I find that large employers are less likely to be subject to an AAER.

Second, my measure of firms' employment reflects a firm's total employees instead of a firm's U.S. employees. To address this concern, I obtain data on firms' U.S. and non-U.S.

\footnotetext{
${ }^{8}$ The SEC's Division of Corporation Finance reviews company filings and sends comment letters to firms if it believes that these filings can be improved (SEC 2013c). As the Division of Corporation Finance may refer cases to the Division of Enforcement, comment letters may trigger an enforcement action.
} 
employees from Compustat Segments and find that about 90 percent of the sample firms do not have employees outside of the U.S. and, moreover, only a firm's U.S. employment is associated with a lower likelihood of SEC enforcement.

This paper contributes to the accounting literature by enhancing our understanding of how regulatory agencies in general and the SEC in particular choose their enforcement targets. While the SEC is the central agency that is responsible for enforcing accounting regulation, not much is known about how this agency selects its enforcement targets. In contrast to studies that have focused on firms' attempts to impact SEC and other regulators' enforcement via lobbying and political connections (Correia 2014; Gordon and Hafer 2005; Hunter and Nelson 1995; Yu and Yu 2011), the findings of my study suggest that, in addition to such lobbying for firms' special interests, the government's efforts to promote the employment conditions are systematically reflected in SEC enforcement. Thus, my study contributes by highlighting that political influence to promote voters' interests affects SEC enforcement, which emphasizes the importance to consider political influence as a response to both voters' and special interests in explaining regulatory agencies' enforcement choices. My study also contributes to prior research in economics and political economy that documents governments' willingness to engage in potentially costly activities to enhance employment conditions. While prior studies show that governments induce pressure on state-owned firms to engage in excess employment (Alesina, Baqir, and Easterly 2000) or bail out firms that are perceived as too big to fail (Adams and Brock 1987a, 1987b), my study sheds light on an additional, more subtle measure to foster employment, i.e., reduced SEC enforcement for large employers. Future research could investigate whether and how the government's preference for employment reflects in other regulatory agencies within and beyond the U.S. 
The remainder of the paper is organized as follows. Section II develops the hypotheses. Section III presents the data and research method, while Section IV provides the empirical results and sensitivity tests. Section V concludes.

\section{HYPOTHESIS DEVELOPMENT}

\section{Government Preferences for Large Employers}

The SEC enforces accounting regulation and oversees the capital markets (SEC 2013c). Its enforcement actions, however, can have significant adverse impacts on the affected firms and stakeholders. Karpoff et al. (2008b), for instance, find that, in addition to the direct penalties, the SEC's enforcement actions can lead to huge reputational penalties imposed by the market. ${ }^{9}$ As a result, about 34 percent of the firms do not survive the enforcement process and thus file bankruptcy. On the other hand, firms that survive face a mean dollar loss of $\$ 591.75$ million from the SEC enforcement action (Karpoff et al. 2008b).

Such potentially severe consequences might incentivize firms to try to influence SEC enforcement to minimize the probability and size of the wealth transfer generated by its enforcement actions (Correia 2014; Watts and Zimmerman 1978). In fact, a considerable stream of literature has shown that firms can establish valuable political connections via lobbying activities or political contributions, and that such politically connected firms are less likely to be involved in enforcement actions from regulatory agencies such as the Internal Revenue Service (Hunter and Nelson 1995), the Environmental Protection Agency (Mixon 1995), and the SEC (Correia 2014; Yu and Yu 2011).

\footnotetext{
${ }^{9}$ In particular, the reputational penalties, i.e., the expected losses in the present value of future cash flows due to lower sales and higher contracting and financing costs, are over 7.5 times the sum of all penalties imposed through the legal and regulatory system (Karpoff et al. 2008b).
} 
While this stream of literature recognizes that the government imposes pressure on regulatory agencies such as the SEC due to firms' political connections, it has not considered that the government might also have preferences independent of firms' active attempts according to which it may influence SEC enforcement. In fact, the regulation models of Stigler (1971) and Peltzman (1976) argue that politicians in general and the government in particular seek to maximize political support, which comes in the form of votes, and thus ensure that their actions also promote voters' interests. A large body of research has since shown that the government indeed represents its voters' interests (e.g., Hibbs 2006; Kalt and Zupan 1984; Mian, Sufi, and Trebbi 2010; Peltzman 1984, 1985, 1992; Potrafke 2012). When deciding whether to re-appoint an incumbent government, empirical studies show that employment conditions significantly influence voters and, as a consequence, employment has been a core interest of governments (Hibbs 2006; Kau, Keenan, and Rubin 1982; MacRae 1977). ${ }^{10}$ Indeed, governments of both parties have long promoted employment by, for instance, establishing policies to support large employers (Nordhaus 1975; Potrafke 2012). These firms receive government support in various forms such as import protection and subsidies in the form of tax favors and bailouts as they contribute significantly to the employment conditions in their industry or region (Adams and Brock 1986, 1987a, 1987b, 2004). ${ }^{11}$ As job losses are a direct consequence of bankruptcy, bankruptcy of large employers can result in more job losses than bankruptcy of less significant employers. Consequently, the government aims to protect large employers from events such as bankruptcy.

\footnotetext{
${ }^{10}$ For instance, Holbrook (1991), who investigates presidential election outcomes for the years 1960 to 1984, finds that for every percentage point of unemployment, the president's party loses 1.2 percent of the vote.

${ }^{11}$ Chrysler, for instance, has been bailed out by the government to prevent huge job losses and destabilization of the entire manufacturing sector at the end of the 1970s and 2000s (Adams and Brock 1987a; Barnes 2009).
} 


\section{SEC Behavior under Government Preferences}

Regulations and regulatory agencies are influenced by the legislative as well as executive branches of federal government, i.e., the Congress and the president (Stigler 1971). In the case of the SEC, Congress decides on the SEC's budget and oversees the SEC, while the president appoints the SEC commissioners with the advice and consent of the Senate (SEC 2013a). According to Weingast (1984), these rather subtle control mechanisms involve little direct participation by the government to ensure that the agency acts in line with government's goals. ${ }^{12}$ For instance, the appointment of commissioners allows the president as well as Senate to impact which political views are represented in the SEC (Noll 1971; SEC 2013a; Weingast 1984). ${ }^{13}$ The commissioners often also have political careers and consequently have incentives to act in accordance with government's interests (Alesina and Tabellini 2007; SEC 2013c). ${ }^{14}$ In fact, anecdotal evidence suggests that the commissioners and senior SEC staff might act in accordance with government's goal to protect large employers. For instance, Robert Khuzami, the former Director of the SEC's Division of Enforcement, states that the SEC has to ask itself "under what circumstances [it] should indict an entire institution for the misconduct of some number of its employees" as such action may cause harm to innocent employees (Orol 2013). According to Khuzami, Arthur Andersen provides a compelling case why an entire institution should not be charged, given that the SEC's and DOJ's enforcement efforts drove the firm to bankruptcy and all employees lost their jobs (Orol 2013). In line with Khuzami's statements,

\footnotetext{
${ }^{12}$ As a more direct form of control, Arthur Levitt, the former Chairman of the SEC (Levitt and Dwyer 2003), describes that politicians can actively intervene with an SEC investigation. For instance, he describes strong pressure from Congress following the proposal of an audit independence rule: "Soon, I was spending almost all my time deflecting a barrage of phone calls, visits and letters from House and Senate Members."

${ }^{13}$ Congress can also use the budget decisions to reward (or punish) agency decisions that increase (or decrease) political support (Weingast 1984).

${ }^{14}$ Christopher Cox was a House Representative for 17 years before becoming the chairman of the SEC in 2005. Kathleen Casey, a former SEC commissioner, was staff director and counsel of the U.S. Senate Banking, Housing and Urban Affairs Committee during the 13 years prior to her SEC appointment (Correia 2014).
} 
Mary Jo White, the current Chair of the SEC, argues that prosecutors should consider the direct and collateral consequences such as the harm to employees when they make a decision as to whether to indict a company as their decision should be "thoughtful and in the public interest" (SEC 2014c). Also in earlier years, SEC Commissioners such as Paul Atkins have emphasized that the consequences of an enforcement action can be devastating to the firms involved, not to mention investors, employees, and many others, and consequently —in line with "the will of Congress"- the SEC weighs the costs and benefits of its actions (SEC 2005). ${ }^{15}$

Such potentially aligned behavior of the commissioners and senior staff could affect the SEC's enforcement process, which is shown in Figure 1, at various stages. ${ }^{16}$

- Figure 1 here -

As the SEC has limited resources, it cannot investigate all firms and consequently has to make choices in its enforcement actions (SEC 2013b). Such choices are influenced by the commissioners. In particular, an enforcement action typically starts with a lead or trigger event such as a restatement, auditor or management departure, unusual trading, or referrals from the SEC's Division of Corporation Finance, among many other sources (SEC 2013b). In designating a lead a priority, the assigned staff is encouraged to use discretion in balancing and weighing various considerations such as the extent of misconduct, the programmatic importance, and the deterrence effect, among other factors (SEC 2013b). The programmatic importance, in particular, is determined by the enforcement priorities that are set by the Commission, i.e., the chair and other commissioners, in cooperation with senior staff (SEC 2014a). Subsequently, the staff has to decide whether to conduct an informal and confidential investigation, called "matter under

\footnotetext{
${ }^{15}$ He highlights that even if a sanction is "light" the mere existence of an enforcement action has severe consequences. Thus, he argues that one-size-fits-all regulatory mandates are often not appropriate (SEC 2005).

${ }^{16}$ Figure 1 is adapted from Karpoff et al. (2008b). A more detailed description of the enforcement process can be found in the SEC enforcement manual (SEC 2013b).
} 
inquire" (MUI). Again, "assigned staff are encouraged to use their discretion and judgment in making the preliminary determination of whether it is appropriate to open a MUI" (SEC 2013b). After this investigation, the assigned staff considers again whether the SEC or Division has designated the subject matter to be a priority. The staff then provides a recommendation to the Branch Chief, and Assistant, Associate as well as Regional Director whether to open a formal non-public investigation or close the MUI. ${ }^{17}$ Based on that recommendation, these senior officers can, at their discretion, issue a Formal Order of Investigation (SEC 2013b) ${ }^{18}$ This high level of discretion, which allows a case-specific consideration of various aspects, the hierarchical structure of the SEC, and the requirement to obtain higher level authorization at each step of the enforcement process further ensure that the investigations conducted are in line with the Commission's priorities. ${ }^{19}$ At the end of the investigation, senior enforcement management reviews the case after which the staff presents an enforcement recommendation to the Commission (GAO 2009) ${ }^{20}$ Each recommendation is presented to the Commission, which votes in a closed meeting whether to approve or reject the recommendation (SEC 2013b). Thus, the Commission can overrule the staff's recommendation and consequently reduce or even prevent enforcement actions against large employers, for instance. If the Commission decides to file charges against the firm, which marks the beginning of the regulation period, the investigation

\footnotetext{
${ }^{17}$ Enforcement personnel are located in SEC's headquarters in Washington, D.C., and the agency's 11 regional offices. An associate director heads each Office of Associate Director and has one or more assistant directors. Branch chiefs report to assistant directors and supervise the work of investigative attorneys (GAO 2009).

${ }^{18}$ The Director of the Division of Enforcement or his designee determines the programmatic importance of each investigation and allocates resources accordingly (SEC 2013b). During the investigation period, the targeted firm may issue a press release indicating that it is the target of an SEC informal inquiry or formal investigation. However, usually the firm does not voluntarily disclose this information (Karpoff et al. 2008b).

19 According to a GAO (2013) study, the arduous process of obtaining the Commission's approval for an enforcement action indeed drives staff to pursue cases in line with Commission's priorities.

${ }^{20}$ At this point in time, the SEC might provide the affected firm with a Wells notice to inform the firm about the staff's determination to recommend that the Commission files an action (SEC 2013b).
} 
can result in a criminal investigation, which is conducted by the DOJ, or an administrative as well as civil action, which are handled by the SEC. ${ }^{21}$

In summary, the anecdotal evidence suggests that the commissioners and senior staff, who decide on each enforcement action, act in line with government's goal to promote employment. Following this argumentation, I propose that the SEC considers the potential harm to employees in its enforcement actions and perceives this harm to be higher for large employers, resulting in a lower likelihood of SEC enforcement against large employers. This argumentation can be summarized in the following hypothesis:

\section{Hypothesis 1: Large employers are less likely to be subject to an AAER.}

\section{Variations in Government's Sensitivity to Voters’ Interests}

Prior research in political economy especially highlights the role of upcoming elections as a period in which the government is likely to respond even more to the needs of its voters to ensure political support in the upcoming election (Brown and Dinc 2005; Hibbing and Alford 1981; Kramer 1971). As Kinder and Kiewiet (1979, 1981) have emphasized, voters often use the current health of the economy as a signal of the incumbent's economic competence that will influence the voter's economic prosperity in the future. Therefore, it is of particular importance for the government to foster employment conditions prior to elections. A large literature on political business cycles, starting with Nordhaus (1975), has highlighted that the incumbent government is indeed willing to induce pressure on regulatory agencies to enhance the current employment conditions or avoid negative news with regard to these conditions. For instance, Hunter and Nelson (1995) and Young et al. (2001) document lower audit rates by the IRS in

\footnotetext{
${ }^{21}$ All proceedings that involve an accountant or an auditor receive a secondary designation by the SEC called an Accounting and Auditing Enforcement Release (AAER) (Kedia and Rajgopal 2011).
} 
states that are important for the presidential election. Also, accounting researchers have shown that elections influence firms' as well as governments' accounting choices (Kido et al. 2012; Ramanna and Roychowdhury 2010). For instance, Kido et al. (2012) find that state governments manipulate accounting numbers to present a healthier financial picture in an election year in order to enhance their reelection prospects.

Therefore, both political economy theory and empirical evidence indicate that the government in general and the presidential administration in particular is likely to place more pressure on regulatory agencies prior to elections. Based on this, I argue that the SEC also faces more political pressure from the government prior to elections. Next to this increased pressure, the commissioners, as their careers often depend on the support of the incumbent government (Alesina and Tabellini 2007), have incentives to intensify actions that provide political benefits to the government. This increased pressure in combination with the increased incentives, consequently, leads to relatively fewer enforcement actions against large employers prior to elections. Thus, I state the following hypothesis:

\section{Hypothesis 2a: Large employers are relatively less likely to be subject to an AAER in presidential election years.}

Such increased political pressure on the SEC or efforts by the SEC in election years are, however, not necessarily constant across states. In fact, prior research has argued and found that during presidential elections the political influence is directed to electoral-vote rich states that are tightly contested to enhance the presidential reelection prospects (or those of the president's party) (Grier, McDonald, and Tollison 1995; McCarty 2000; Young et al. 2001). For instance, Grier et al. (1995) find that the president's decision to veto a bill can be predicted by the votes of senators from electorally important states. Young et al. (2001) find that the fraction of individual 
income tax returns audited is lower in districts that are important to the president electorally. Mebane and Wawro (1993) also show that the president specifically targets spending toward areas that are important for his reelection. These results suggest that the presidential administration may use the veto and other perquisites of the office to favor some states over others. Based on this argumentation, I argue that in presidential election years the SEC faces more political pressure to spare large employers based in politically important states, i.e., electoral-vote rich states that are tightly contested. Thus, I state the following hypothesis:

\section{Hypothesis 2b: In presidential election years, large employers are relatively less likely to be subject to an AAER if they are based in politically important states.}

Research in political economy shows that a congressional district's employment conditions affect voters' support for members of the House (e.g., Goodman and Kramer 1975). In contrast to the president, members of the House have to contest in elections every two years. These frequent elections heightens the importance for congressmen to constantly—and not just before elections - act in the interest of their voters (Gartzke and Wrighton 1998). ${ }^{22}$ A congressman is likely to be especially sensitive to his/her district's employment conditions if the local unemployment rate is higher than in other districts (Gartzke and Wrighton 1998; Kiewiet and McCubbins 1985). Kiewiet and McCubbins (1985), for instance, find that higher levels of appropriations - especially for public works agencies - are allocated to districts with higher unemployment rates. Following this argumentation, I hypothesize that firms that employ a larger proportion of the total workforce of the district where they are based ("locally large employers")

\footnotetext{
${ }^{22}$ I focus on members of the House for three reasons. First, members of the Senate serve on six-year terms, potentially reducing the need to constantly act in the interest of voters. Second, while each congressional district is represented by one congressman, each state is represented by two senators, making it theoretically as well as empirically difficult to allocate political influence on the SEC to one of these senators. Third, during the time period of my sample about $95 \%$ of all states had at least one of a state's two senators serving on a committee that oversees the SEC, resulting in a lack of variation of Senators' power over the SEC.
} 
are less likely to be subject to an AAER if their district exhibits a high unemployment rate. Thus, I state the following hypothesis:

Hypothesis 2c: Locally large employers are less likely to be subject to an AAER if they are based in districts that exhibit a higher unemployment rate than other districts.

Such increased political pressure on the SEC is, however, likely to vary across districts as the ability of congressmen to influence the SEC is not constant (Correia 2014; Weingast 1984). Weingast (1984), in particular, argues that "it is not the Congress as a whole that is relevant for policymaking but rather the committee(s) with jurisdiction over the agency". In contrast, "members not on the relevant committee [...] have substantially less power" (Weingast 1984). In the case of the SEC, members of the House serving on the House Appropriations, Banking and Commerce committee are likely to have the largest influence on the SEC as the House Financial Services or Banking as well as the Commerce Committee oversee the SEC, while the Appropriations Committee decides on the SEC's appropriations (Correia 2014; Weingast 1984). ${ }^{23}$ As a consequence, the SEC has incentives to act in accordance with the interest of these congressmen. Therefore, while all congressmen whose unemployment rate is higher than in other districts might benefit from reduced SEC enforcement against locally large employers, I argue that such reduced enforcement against locally large employers that are based in districts with a high unemployment rate is more pronounced if the incumbent congressman serves on a committee that oversees the SEC. Thus, I state the following hypothesis:

Hypothesis 2d: Locally large employers that are based in districts with a high unemployment rate are less likely to be subject to an AAER if the incumbent congressman serves on a committee that oversees the SEC.

\footnotetext{
${ }^{23}$ The SEC Chair, for instance, regularly has to provide testimony at the Banking committee (SEC 2014b).
} 


\section{DATA AND RESEARCH METHOD}

\section{SEC Enforcement Data}

To investigate SEC enforcement I use a sample of firms that have been subject to enforcement actions by the SEC for allegedly misstating their financial statements as reported in AAERs. Using the SEC's AAERs as a sample of misstatement firms has several advantages relative to other potential samples. First, AAERs capture SEC enforcement, while other samples such as the Government Accountability Office (GAO) Financial Statement Restatement Database or the Stanford Law Database on Shareholder Lawsuits capture events that are not necessarily related to SEC enforcement (Dechow et al. 2011). ${ }^{24}$ Second, the use of AAERs as a proxy for manipulation is a straightforward and consistent methodology that avoids potential biases induced in samples based on researchers' individual classification schemes and can be easily replicated by other researchers (Dechow et al. 2011). Third, using the SEC's AAERs also allows me to use the F-score, which is a potentially powerful proxy for a firm's accounting quality in this specific setting, as the F-score has been developed to predict AAERs (Dechow et al. 2011). Despite the advantages of using AAERs, the main disadvantage, which is common to studies that also consider additional enforcement actions (e.g., Kedia and Rajgopal 2011), is that AAERs represent the end product of investigations as opposed to the initial investigations. To test whether the government's preferences impact the SEC's enforcement actions, I would ideally like to study all investigations undertaken by the SEC. However, data on investigations that did not eventually convert into enforcement actions are not publicly available, and therefore I cannot

\footnotetext{
${ }^{24}$ In contrast to the restatement database, AAERs also span a larger time period, state the reporting periods that were misstated, and are likely to only include events that occurred as a consequence of intentional misstatements rather than misinterpreting accounting rules (Dechow et al. 2011; Plumlee and Yohn 2010).
} 
investigate at which stages of the enforcement process preferences for significant employers actually affect this very process. ${ }^{25}$

I obtain the data on AAERs from Dechow et al. (2011). All enforcement actions that involve an accountant or an auditor are designated as an AAER by the SEC, which is my measure of the SEC's enforcement actions. The SEC has issued AAERs during or at the conclusion of an investigation since 1982. Therefore, my sample spans the time period 1982 to 2012, and consists of 3,403 AAERs, which refer to 1,838 misstated firm-years against 789 distinct firms.$^{26}$ After excluding AAERs that occur in financial industries, i.e., two-digit SIC codes 60-69, and matching the remaining misstatement events to firms' publicly available data in Compustat and the Center for Research in Security Prices (CRSP), I have a remaining sample of 694 AAER firm-years with available data, representing AAERs against 306 distinct firms (see Table 1 for a detailed description of the AAER sample selection) ${ }^{27}$ Thus, the misstatement of the average AAER firm in my sample lasts for two fiscal years. Including my sample of control firms, i.e., all non-AAER firms with available data for the same time period, I arrive at an overall sample of 93,207 firm-year observations, representing 11,400 distinct firms. ${ }^{28}$

\footnotetext{
${ }^{25}$ As an additional test, I investigate whether large employers receive fewer SEC comment letters. As these letters might trigger an enforcement action, investigating the likelihood of receiving these letters provides some insights at which stage of the SEC investigation process the SEC adjusts its enforcement actions in accordance with the government's preferences.

${ }^{26}$ Note that multiple AAERs may pertain to a single set of misstatement events at a single firm because the SEC can take action against multiple officers as well as the firm itself. The number of AAERs ranges from one per firm to a high of 46 per firm (Enron).

${ }^{27}$ I exclude financial industries as calculating accounting quality measures is difficult for these firms. Including financial industries does not affect my results and increases the number of AAER firm years (firms) by 26 (9).

${ }^{28}$ Instead of comparing an AAER firm to the average non-AAER firm, I also examine the incidence of AAERs in a sample of firms subject to class action lawsuits as reported in my sensitivity tests. Such firms potentially engaged in accounting irregularities, and the class-action lawyers have no reason to consider employment consequences of their actions.
} 


\section{Methodology}

To test whether large employers are less likely to receive an AAER, I use two different research designs. First, I examine the likelihood of receiving an AAER using the following logistic regression model where subscript $i$ represents the firm and $t$ the year:

$$
\text { AAER Dummy }_{i t}=\beta_{0}+\beta_{1} \text { Log Employees }_{i t}+\sum_{n} \beta_{n} \text { Controls }_{i t}+e_{i t}
$$

The AAER DUMMY is an indicator variable that is equal to one in the years the misstatements occurred as reported in the Accounting and Auditing Enforcement Releases, and zero otherwise (Dechow et al. 2011). To identify large employers, I use the natural logarithm of the number of employees, denoted LOG EMPLOYEES. H1 predicts a negative coefficient on $\beta_{1}$, i.e., more employees will be associated with a lower likelihood of receiving an AAER.

Second, I form matched pairs using propensity score matching (PSM). In particular, I match firms in the largest employment-size quartile with firms outside this employment-size quartile that do not exhibit any significant differences along a set of observable firm characteristics (Dehejia and Wahba 2002; Rosenbaum 2002). This approach allows me to attribute any difference in the likelihood of SEC enforcement for top quartile versus non-top quartile employers more appropriately to differences in firms' number of employees, rather than differences in any other observable firm characteristic. I estimate the probability that a firm will be in the top quartile of employment (i.e., the treatment) conditional on observable firm characteristics using the following probit regression model, where subscript $i$ represents the firm and $t$ the year:

$$
\text { Top Quartile Log Employees } \text { Em }_{i}=\beta_{0}+\sum_{n} \beta_{n} \text { Controls }_{i t}+e_{i t}
$$


I group firms in the top quartile of employment versus all other firms for two reasons. First, as I do not have a binary treatment, I have to create a cutoff point (e.g., median, quartiles, deciles) for my measure of large employers (Armstrong et al. 2010). Second, using the top quartile as cutoff point allows me to form pairings that result in observations with insignificant propensity-score differences while minimizing the loss of firms for which I cannot find a good match. Next, I form matched pairs by selecting an observation that received the treatment, i.e., top quartile of employment, and selecting another observation within a predefined propensity score radius (or "caliper") of 0.0005 that did not receive the treatment. The propensity scores range from 0 to 1 and about one quarter of observations have propensity scores smaller than the predefined radius of 0.0005 . The smaller the radius, the more likely it is to form pairs that do not exhibit significant differences on the observables (Dehejia and Wahba 2002). ${ }^{29}$ This matching process is done without replacement, indicating that treatment observations do not have the same non-treatment observation as a pair. As a third step, I examine the covariate balance between the treatment and control samples to ensure that my matched pairs are similar across all observable firm characteristics. To test H1, I measure the difference in the likelihood of receiving an AAER between top quartile employers and the matched non-top quartile employers. Finally, in line with prior research (Armstrong et al. 2010), I also assess the sensitivity of these results to "hidden bias", or unobserved correlated omitted variables, using the bounding techniques developed by Rosenbaum (2002).

To test hypothesis $2 \mathrm{a}$, whether firms that are large employers are less likely to be subject to an AAER in election years, I adjust the logistic regression model for testing H1 by including an ELECTION YEAR indicator, which is an indicator variable that is one in all presidential election

\footnotetext{
${ }^{29}$ For instance, nearest neighbor matching is less appropriate in my setting as the nearest non-top quartile employer often differs significantly to a top quartile employer.
} 
years during the period 1982-2012 (i.e., 1984, 1988, 1992, 1996, 2000, 2004, 2008 and 2012), and zero otherwise.$^{30}$ As presidential elections coincide with Congressional elections, these years represent higher scrutiny of voters towards their government. Thus, I use these years as my proxy for government's sensitivity towards voters' interests prior to elections. I interact this indicator variable with LOG EMPLOYEES. The underlying argument of $\mathrm{H} 2 \mathrm{a}$ is that the government is willing to exert more influence on the SEC to avoid negative news with regard to the employment conditions. Although the SEC investigations are supposed to be confidential, such investigations can be revealed by the media, other stakeholders or even the firm itself (Karpoff et al. 2008b). As the negative consequences for firms largely materialize at the point in time the market first learns about an SEC investigation, instead of the release of an AAER, which lags the initial revelation of the misconduct by on average over 1,000 days (Karpoff et al. 2008b), the SEC is likely to initiate fewer investigations against large employers in election years, instead of simply postponing the release of an AAER until after the election. While media reports or firms' press releases can provide information that a firm is the target of an SEC investigation, these releases do not allow identifying the start date of an SEC investigation. ${ }^{31}$ Thus, I use the same dependent variable as for testing H1, denoted AAER DUMMY, which is one in the year the misstatement has occurred, instead of the year when the AAER has been released. A limitation of this design is that it assumes that fewer investigations against large employers in election years result in a lower likelihood to ultimately detect misstatement by large employers in

\footnotetext{
${ }^{30}$ As the matching process excludes observations for which no similar pair can be found, my matched sample includes few AAER firms and consequently decreases the statistical power of my analyses. Therefore, I do not test $\mathrm{H} 2$ with this alternative research design.

${ }^{31}$ For instance, more than $70 \%$ of the firms that decide to disclose that they are the target of an SEC investigation disclose that information after a formal investigation has been initiated, i.e., shortly before the SEC decides to charge files (Karpoff et al. 2008b).
} 
election years as reported in AAERs. H2a predicts a negative coefficient on the interaction of larger employment and the election year indicator.

To test hypothesis $2 \mathrm{~b}$, whether in election years large employers are less likely to be subject to an AAER if they are located in politically important states, I adjust the logistic regression model for testing H2a by including an indicator variable, denoted IMPORTANT STATE, and interaction terms with large employers and the election year indicator. In line with prior research that argues and finds that presidential campaign resource allocations are concentrated in closelycontested states with a high Electoral College count (Brams and Davis 1974; Grier et al. 1995), the variable IMPORTANT STATE captures the margin of victory as well as the number of Electoral College votes in each state. In particular, I follow Cebula et al. (2013) and express the political importance of a state by dividing the number of Electoral College votes at stake by the margin of victory for the winning candidate. The states are then ranked in descending order for each U.S. presidential election (see Appendix A). IMPORTANT STATE is an indicator variable that is one for the top ten most important states, and zero otherwise. ${ }^{32} \mathrm{H} 2 \mathrm{~b}$ predicts a negative coefficient on the interaction between the election year indicator, large employers, and the important state indicator.

To test hypothesis $2 \mathrm{c}$ whether locally large employers that are headquartered in districts with high unemployment rates are less likely to be subject to an AAER, I adjust the logistic regression model for testing $\mathrm{H} 1$ by replacing LOG EMPLOYEES with LOCAL EMPLOYEES. LOCAL EMPLOYEES is a firm's workforce in proportion to the congressional district's total workforce. To measure a firm's share of total employment per district, I obtain data from Garcia and Norli

\footnotetext{
${ }^{32}$ For instance, according to that metric Florida and Ohio are in the top ten of the 2008 list. Obama-Biden won Florida's 27 Electoral College votes by a margin of 236,450 popular votes, and Ohio's 20 Electoral College votes went to Obama-Biden by a margin of 262,224 popular votes. California, the most populous state, was near the bottom of the 2008 list. California's 55 Electoral College votes went to Obama-Biden by a margin of about 3.3 million popular votes (Cebula et al. 2013).
} 
(2012) for the period 1994-2008 who developed a method to allocate firms' employees to their headquarter state based on the number of times the headquarter state name is mentioned in firms' 10-Ks relative to all other state names. ${ }^{33}$ The average firm in my sample mentions eight states in its $10-\mathrm{K}$ out of which the headquarter state is referred to most often, i.e., 45 percent of all state occurrences refer to the headquarter state. Finally, I obtain data from the U.S. Census Bureau on the total workforce per congressional district and scale firms' adjusted number of employees by the workforce per congressional district. In addition, I include HIGH UNEMPLOYMENT DISTRICT, which is an indicator variable that is one for all districts whose unemployment rate is larger than the average unemployment rate per year and state, and zero otherwise. H2c predicts a negative coefficient on the interaction of locally large employers and the high unemployment district indicator.

To test hypothesis $2 \mathrm{~d}$ whether locally large employers that are headquartered in districts with high unemployment rates and congressmen serving on an SEC committee are less likely to be subject to an AAER, I adjust the logistic regression model for testing $\mathrm{H} 2 \mathrm{c}$ by including an indicator variable, denoted SEC COMMITTEE, and interactions with locally large employers and the high unemployment district indicator. SEC COMMITTEE is an indicator variable that is one if a firm's headquarters are located in a congressional district with a congressman who serves on the House Appropriations, Banking or Commerce committee, and zero otherwise. These committees are responsible for overseeing the SEC and deciding on the SEC's appropriations (e.g., Correia 2014; Weingast 1984). To construct this variable I obtain data from Charles Stewart's Congressional Data webpage for all members of the House for the period 1982-2012 and match every firm to a specific district based on its zip code as reported in Compustat. H2d

\footnotetext{
${ }^{33}$ Garcia and Norli (2012) count the occurrence of state names in sections "Item 1: Business", "Item 2: Properties", "Item 6: Consolidated Financial Data", and "Item 7: Management's Discussion and Analysis" of firms' 10-Ks as of 1994 (when EDGAR filing started).
} 
predicts a negative coefficient on the interaction between the SEC committee indicator, locally large employers, and the high unemployment district indicator. ${ }^{34}$

I include several control variables, denoted CONTROLS. First, to control for a firm's accounting quality, I use the F-score developed by Dechow et al. (2011). ${ }^{35}$ Dechow et al. (2011) investigate characteristics of misstating firms and develop a model to predict misstatements, i.e., AAERs. The output of this analysis is a scaled probability (F-score) that can be used as a red flag of the likelihood of earnings misstatement (Dechow et al. 2011). The different F-scores either include (1) only financial statement variables (F-SCORE 1), (2) financial statement, off-balance sheet, and nonfinancial variables (F-SCORE 2), or (3) financial statement, off-balance sheet, nonfinancial, and stock market-based variables (F-SCORE 3). In different specifications of my models I either include F-SCORE 1, F-SCORE 2, or F-SCORE 3. The higher the resulting Fscore, the higher is the likelihood of earnings misstatement.

As the SEC is more likely to investigate firms located closer to its offices (Kedia and Rajgopal 2011), I control for the distance between the county of a firm's headquarters and SEC offices in Washington, DC, New York City, NY, Miami, FL, Chicago, IL, Denver, CO, and Los Angeles, CA, using the latitude and longitude of both counties and SEC offices obtained from

\footnotetext{
${ }^{34} \mathrm{http} / / /$ web.mit.edu/17.251/www/data_page.html. In unreported tests, I exclude all firms located in states that only have one congressional district (i.e., Alaska, Delaware, Montana, North Dakota, South Dakota, Vermont, and Wyoming) to rule out that my results are driven by state level effects. The results are unaffected by excluding firmyear observations from these states.

35 The F-score might also partly capture the SEC's selection criteria (Dechow et al. 2011). From a firm's perspective, however, being subject to an SEC enforcement action is very costly, making it beneficial for firms to avoid these characteristics and therefore the F-score is likely to mainly capture characteristics of firms that are more likely to misstate their financial statements as opposed to the SEC's selection criteria (Dechow et al. 2011). In untabulated tests, I also use discretionary accruals according to the modified Jones model (Dechow, Sloan, and Sweeney 1995) and the Dechow and Dichev (2002) model to control for a firm's accounting quality. My results are robust to these alternative measures.
} 
the U.S. Census Bureau Gazetter. ${ }^{36}$ Based on these distances I create a dummy, PROXIMATE 100, which is equal to one for firms located within $100 \mathrm{~km}$ of the SEC office.

As Correia (2014) and $\mathrm{Yu}$ and $\mathrm{Yu}$ (2011) find that politically connected firms enjoy a favorable treatment by the SEC, I obtain data on firms' Political Action Committee (PAC) contributions from the Federal Election Commission's (FEC) website (www.fec.gov) to control for firms' political connections. ${ }^{37}$ I match the PAC contributions to my sample of Compustat firms and measure political connections by scaling firms' PAC contributions by total average assets, denoted PAC CONTRIBUTION. ${ }^{38}$

I also obtain data on the percentage of employees who are union members per four-digit SIC code, denoted UNION, from the Union Membership and Coverage Database maintained by Hirsch and Macpherson (2003) to rule out that my results are primarily driven by pressure from unions. ${ }^{39} \mathrm{I}$ also include the natural logarithm of the number of analysts issuing annual earnings forecasts for firms covered by IBES, denoted LOG ANALYST FOLLOWING, and an indicator variable, FORTUNE 500, that is one if the firm is covered in the Fortune 500 index as reported in Compustat, and zero otherwise, to control for firms' visibility (Correia 2014).

In accordance with prior studies (Brazel, Jones, and Zimbelman 2009; Ettredge, Sun, Lee, and Anandarajan 2008), I control for several firm characteristics. First, I include a firm's two-

\footnotetext{
${ }^{36}$ I use the Haversine formula to calculate the distance between counties and SEC offices. In 2007 the SEC elevated its district offices in Boston, MA, Philadelphia, PA, Atlanta, GA, Fort Worth, TX, Salt Lake City, UT, and San Francisco, CA to regional offices. In line with Kedia and Rajgopal (2011), I only consider a firm's distance to the original regional offices. Considering the additional regional offices does not affect my results.

${ }^{37}$ A PAC is a political committee that is organized to raise money to elect or defeat candidates. It can be sponsored by a corporation that can cover the PAC's operating costs but cannot contribute directly to the PAC. Instead, PACs solicit contributions from executives, employees, and shareholders of the firm. The decision to distribute PAC contributions typically belongs to the top executives of the firm (Correia 2014). PAC contributions are widely used as a proxy for political connections (see Milyo, Primo, and Groseclose 2000, for an overview) and the FEC compiles this data from 1978 onwards, covering my whole sample period.

${ }^{38}$ I also obtain data on firms' lobbying expenditures from the Center for Responsive Politics (CRP) as an alternative measure for firms' political connections (Blau, Brough, and Thomas 2013; Correia 2014; CRP 2013). As the CRP compiles this data only from 1998 onwards, these tests are limited to the period 1998-2012. My results are robust to this alternative measure (see Table 3 ).

${ }^{39}$ This database is publicly available at www.unionstats.com.
} 
digit SIC code median-adjusted return on assets, denoted ROA, to control for a firm's performance. ${ }^{40}$ Next, I construct a dummy variable, denoted $B I G 4$, which is one for all firms audited by a Big 4 firm, and zero otherwise. As Big 4 auditors are potentially of higher quality (Defond 1992), clients of the Big 4 might be less likely to commit fraud. I use the MARKET-TO$B O O K$ ratio to control for a firm's growth expectations. ${ }^{41}$ A firm's $L E V E R A G E$ is included to control for a firm's financial distress (Brazel et al. 2009) as financially distressed firms may have a greater incentive to commit fraud. The natural logarithm of a firm's age, denoted LOG FIRM $A G E$, controls for the fact that fraud firms tend to be younger (Beneish 1997). To control for size I include the natural logarithm of a firm's total assets, LOG ASSETS. I include industry and year fixed effects. Finally, I include fixed effects for the tenure of each SEC Chairman and each U.S. President to control for tenure-specific policy priorities. ${ }^{42}$ Standard errors are clustered by firm. Appendix B provides an overview of my variables.

\section{Descriptive Statistics}

Table 2 reports descriptive statistics of my sample, a comparison between larger and smaller employers, and a comparison of the AAER vs. non-AAER firms.

As reported in Table 2, Panel A, the mean (median) firm in my sample has total assets of $\$ 1,808$ million ( $\$ 141$ million), 6,823 (837) employees of which on average $11.5 \%$ are union members, leverage of .179 (.119), a market-to-book ratio of $2.8(1.8)$, and is 15 (10) years old. The skewness of these distributions suggests that my sample includes proportionately smaller and younger firms. The majority of firms are audited by a Big 4 auditor (81.4\%), 31.3\% of the

\footnotetext{
${ }^{40}$ Above average financial performance may indicate that the firm is achieving abnormally high performance through fraudulent reporting, or that the firm may have incentives to commit fraud in order to sustain their performance (Brazel et al. 2009).

${ }^{41}$ Dechow et al. (1996) find that firms with higher growth opportunities are more likely to manipulate earnings.

${ }^{42} \mathrm{http}: / / \mathrm{www} \cdot \mathrm{sec}$.gov/about/sechistoricalsummary.htm.
} 
firms are located within $100 \mathrm{~km}$ distance to a major SEC office, and are followed by 4.5 analysts on average. Furthermore, $27.4 \%$ of the firms contribute to PACs, spending on average $\$ 14,646$ per year, and during the time period 1998-2012, 16.2\% of the firms engage in lobbying, spending on average $\$ 71,621$.

Table 2, Panel B reports the differences between larger and smaller employers. ${ }^{43}$ The descriptives indicate that larger employers are significantly larger, older, more profitable, more likely to have a Big 4 auditor, have more analyst following, have more leverage, contribute more to PACs and engage in more lobbying. Furthermore, larger employers have significantly higher F-scores, higher abnormal accruals, and a larger share of them is located further away from an SEC office.

Table 2, Panel $\mathrm{C}$ shows the differences between the firms that received an AAER and firms that did not. AAER firms have a higher F-score, are located closer to an SEC office, are more profitable, are more likely to be audited by a Big 4 auditor, have more analysts following, have higher growth expectations as measured by the market-to-book ratio, are younger and larger. This is consistent with the perception that the SEC is more likely to target large firms and firms located closer to its offices (Kedia and Rajgopal 2011). I also find that a larger share of AAER firms contributes to PACs and that the absolute contribution amounts are larger. The descriptives also show that AAER firms employ more people as they are much bigger in size and operate in industries with a lower percentage of union members. However, AAER firms employ significantly fewer people than the average large employer as reported in Panel B. These findings provide preliminary support for $\mathrm{H} 1$.

- Table 2 here -

\footnotetext{
${ }^{43}$ I split the sample at the median value of number of employees into two groups.
} 


\section{RESULTS}

\section{Test of $\mathbf{H 1}$}

Table 3, Panel A shows the results of estimating equation 1, which examines the likelihood of being subject to an AAER. Consistent with $\mathrm{H} 1$, the negative and significant coefficient on log employees $\left(\beta_{1}\right)$ in all of the models indicates that large employers are less likely to receive an AAER. These results indicate that the SEC is less likely to prosecute large employers. The control variables are in line with prior research. In particular, the positive and significant coefficients on all three types of F-score indicate that firms with a higher F-score are more likely to receive an AAER (Dechow et al. 2011). Consistent with Kedia and Rajgopal (2011), I show that firms located closer to the SEC's main offices are more likely to receive an AAER, as shown by the positive and significant coefficient on the PROXIMATE 100 dummy. Consistent with Correia (2014), firms with higher lobbying expenditures relative to their size are less likely to be subject to an AAER, as indicated by the negative and significant coefficient on LOBBYING EXP in Model 4. In line with prior research (Brazel et al. 2009), I also find a negative and significant coefficient on the Big 4 dummy, suggesting that clients of the Big 4 are less likely to commit fraud. Finally, I also find that larger (as measured by log assets) and younger firms as well as firms with larger growth potential and more analysts following are more likely to be subject to an AAER.

Table 3, Panel B shows the results of the first step of PSM, i.e., the probit propensity-score model. The model includes the same variables as equation 1 except for LOG EMPLOYEES. All variables are defined as before and as described in Appendix B. The results are similar to the descriptive statistics reported in Table 2, Panel B. After matching top quartile firm observations to non-top quartile firm observations based on the propensity scores obtained from the 
propensity-score model, I have a matched sample of 16,496 firm-year observations, including 152 AAER firm-year observations. As reported in Table 3, Panel B, the results of the mean comparisons of matched pairs indicate that the matching procedure successfully finds non-top quartile large employers that do not exhibit any significant differences to the top quartile large employers in any of the variables used in the matching procedure. To test H1, I measure the difference in the likelihood or receiving an AAER between firms that are in the top quartile of employment and the matched non-top quartile large employers. As shown in Table 3, Panel C, the matched non-top quartile employers are more likely to receive an AAER than the matched top quartile employers. In particular, mean top quartile large employers have a probability of 0.005 to receive an AAER, while mean matched non-top quartile large employers have a probability of 0.013 to receive an AAER, resulting in an economically significant difference of 0.008. In addition, relative to the unconditional probability of being subject to an AAER, which is 0.0074 , being a top quartile employer decreases the likelihood of being subject to an AAER by about 31 percent. Thus, the propensity score matching provides additional evidence in favor of H1 and highlights the economic significance of my results.

These results, however, might be susceptible to hidden bias caused by the omission of unobservable yet relevant variables, i.e., correlated omitted variables (Armstrong et al. 2010). In line with prior research (e.g., Armstrong et al. 2010), I use a bounding approach developed by Rosenbaum (2002) to assess the sensitivity of my results to such potential hidden bias. In particular, I relax the assumption that matched observations with identical observable covariates have an identical probability of hiring the same number of employees. By relaxing this probability or odds ratio (denoted as $\Gamma$ by Rosenbaum (2002)), I can quantify the potential impact of omitted variables on the observed statistical association between treatment and 
outcome. I find that my results would still be marginally significant if non-top quartile employers were actually 1.55 times, i.e., $\Gamma=1.55$, more likely to be a non-top quartile employer than top quartile employers, after conditioning on observable firm characteristics. As Armstrong et al. (2010) describe, no objective benchmark exists to determine whether a given $\Gamma$ is "large" or "small". Thus, this finding only provides insights how robust the results are to hidden bias, but the assessment of the sensitivity of these results is rather subjective and depends on the beliefs as to the degree of unobservable factors for large employers (Armstrong et al. 2010). Note that one reason for the cross-sectional tests described in $\mathrm{H} 2$ is to provide more robust evidence that my findings are not driven by unobserved correlated omitted firm characteristics of large employers.

- Table 3 here -

\section{Test of $\mathbf{H 2}$}

Model 1 in Table 4, Panel A present the results of estimating the probability of being subject to an AAER in a presidential election year to test H2a. The results show a negative and significant coefficient on a firm's number of employees and the election year indicator. However, I do not find that larger employers are less likely to receive an AAER in an election year, as indicated by the insignificant coefficient on the interaction term between the election year indicator and a firm's number of employees. While these results suggest that the overall level of enforcement actions decreases in election years, which is consistent with governments' attempts to avoid negative news with regards to employment conditions in election years, they do not provide evidence that significant employers are relatively less likely to receive an AAER in a presidential election year. As the coefficient on LOG EMPLOYEES stays significant in all models, the results suggest that large employers enjoy in general a favorable treatment by the SEC, and not just in election years. 
Model 2 of Panel A presents the results of estimating the probability of being subject to an AAER in a presidential election year if headquartered in a politically important state to test $\mathrm{H} 2 \mathrm{~b}$. The results show a negative and significant coefficient on a firm's number of employees, the election year indicator, and the interaction term between the election year indicator, being headquartered in a politically important state and a firm's number of employees. Thus, in line with $\mathrm{H} 2 \mathrm{~b}$, I find evidence that the lower likelihood of SEC enforcement against large employers in presidential election years is concentrated on firms headquartered in politically important states, suggesting that the political influence on the SEC is directed to electoral-vote rich states that are tightly contested to enhance the presidential reelection prospects (or those of the president's party). Moreover, the election year indicator remains negative and significant, suggesting that the SEC engages in less enforcement actions during presidential election years.

Model 2 of Panel B presents the results of estimating the probability of being subject to an AAER for locally large employers, which on average employ 0.8 percent of a district's workforce, headquartered in districts with high unemployment rates to test $\mathrm{H} 2 \mathrm{c} .{ }^{44}$ The results show a negative and significant coefficient on a firm's share of a district's total workforce, and the interaction term between locally large employers and the high unemployment indicator. Thus, in line with $\mathrm{H} 2 \mathrm{c}$, the results suggest that locally large employers are less likely to be subject to SEC enforcement if they are headquartered in districts with unfavorable employment conditions, suggesting that the SEC acts in line with House members' preference for local employment.

Model 3 of Panel B presents the results of estimating the probability of being subject to an AAER for locally large employers headquartered in districts with relatively high unemployment rates and congressmen that serve on a committee that oversees the SEC to test H2d. The results

\footnotetext{
${ }^{44}$ For completeness, Model 1 of Panel B presents the results without any interaction terms.
} 
show a negative and significant coefficient on a firm's share of a district's total workforce, and the interaction term between locally large employers, the high unemployment indicator, and the SEC Committee indicator. Thus, the results show that locally large employers that are headquartered in districts with unfavorable employment conditions are less likely to be subject to SEC enforcement if they are headquartered in a district of a congressman who serves on a committee that oversees the SEC, suggesting that the SEC only acts in line with House members' preference for local employment if these congressmen serve on committees that oversee the SEC.

These results are subject to two issues that may lead to multicollinearity problems. First, the correlation between LOG EMPLOYEES and LOG ASSETS is 0.71, which is relatively high but still below 0.80, the point beyond which multicollinearity becomes a concern (Christie, Kennelley, King, and Schaefer 1984; Wooldridge 2002). ${ }^{45}$ Second, the inclusion of two- and three-way interactions might lead to multicollinearity. To address this concern, I determine the variance inflation factor (VIF) scores for all of the prior models. The VIF scores in all of the models are lower than 10 indicating that multicollinearity is not a problem (Wooldridge 2002).

The results for the control variables remain largely unchanged to the results reported in Table 3, Panel A and are thus not discussed in detail.

- Table 4 here -

\section{Sensitivity Tests}

\section{Accounting Quality of Large Employers}

A potential alternative explanation for fewer enforcement actions against large employers is that these firms have a higher accounting quality than less significant peers. In addition to

\footnotetext{
${ }^{45}$ Note that alternative measures for firm size such as sales or market value are even more highly correlated with a firm's number of employees, i.e., 0.82 and 0.75 , respectively.
} 
controlling for firms' accounting quality in my main models, I therefore run several tests using all three specifications of the F-score as developed by Dechow et al. (2011), discretionary accruals based on the modified Jones model as in Dechow et al. (2011) and the Dechow and Dichev (2002) model, and the incidence of accounting restatements as proxies for a firm's accounting quality (see Appendix B for a detailed description of these proxies). In accordance with prior studies, I control for firm performance, Big 4 auditor, firms' growth expectations, leverage, firm age, and firm size (e.g., Beneish 1997; Dechow et al. 1996). All variables are defined as described in Appendix B. As shown in Table 5, the coefficient on LOG EMPLOYEES is positive and significant in all models (except when using restatements as a proxy for a firm's accounting quality). While each of the accounting quality measures has its drawbacks (Dechow et al. 2011; Price, Sharp, and Wood 2011), in sum, these findings suggest that large employers do not have a higher accounting quality. Instead, the results suggest that large employers exploit their preferential treatment by the SEC and engage in more aggressive accounting choices. The coefficients on the control variables are similar to prior research, i.e., firms audited by a Big 4 auditor and older firms have a higher accounting quality; growth firms a lower accounting quality.

- Table 5 here -

\section{Comment Letters}

While my main tests use AAERs, which are the end product of investigations as opposed to the initial investigations, I also conduct additional tests using SEC comment letters to provide more insights at what stages of the enforcement process government preferences are likely to influence SEC enforcement. The SEC's Division of Corporation Finance reviews company filings and sends comment letters to firms if it believes that these filings can be improved (SEC 
2013c). ${ }^{46}$ The company will typically respond by sending a letter to the SEC and there may be several rounds of correspondence until the SEC advises the company that the review of the filing is complete (Cassell, Dreher, and Myers 2013). As the Division of Corporation Finance may refer cases to the Division of Enforcement, comment letters may trigger an enforcement action. ${ }^{47}$ A resource-constrained SEC that is likely to adjust its enforcement actions in accordance with government's preference for employment might allocate fewer resources to reviews of large employers. As a consequence, large employers are less likely to receive a comment letter and receive fewer comment letters, respectively. To test this premise, I adjust model 1 by replacing the AAER DUMMY with the COMMENT LETTER variable, which is either the number of letters exchanged between a company and the SEC or an indicator variable that is one in the years a firm received a comment letter from the SEC, and zero otherwise. The analysis spans the period 2004 (first year comment letters are publicly available) to 2010. All other variables are defined as before.

As shown in Table 6, I do not find that large employers are less likely to receive a comment letter. However, as the SEC reviews larger firms more often, it is not surprising that large employers are not less likely to receive a comment letter. Instead, I find that large employers receive fewer comment letters, which measures the intensity of the SEC's review (Cassell et al. 2013) and thus suggest that the SEC allocates fewer resources to reviews of large employers, which might result in fewer investigations and ultimately enforcement actions by the Division of Enforcement. I also find that firms that have a higher F-score and are located further away from the SEC office are more likely to receive a comment letter and have a more extensive

\footnotetext{
${ }^{46}$ Since the passage of the Sarbanes Oxley Act, the SEC is required to undertake some level of review of a firm's filings at least once every three years (Kedia and Rajgopal 2011).

${ }^{47}$ For instance, Feroz et al. (1991) refer to a speech by Robert Sack, the former Chief Accountant of the Enforcement Division, who indicated that the SEC obtains 50 percent of the leads from these reviews.
} 
correspondence with the SEC, suggesting that the SEC reviews firms that have a higher likelihood of earnings misstatement more often (Cassell et al. 2013).

- Table 6 here -

\section{Class Action Lawsuits Sample}

Instead of comparing an AAER firm to the average non-AAER firm, it might be more appropriate to examine the incidence of AAERs in a sample of firms subject to class action lawsuits. Such firms potentially engaged in accounting irregularities, and the class-action lawyers have no reason to consider employment consequences of their actions. Therefore, I obtain the sample of 2,225 class action lawsuits from the Stanford Law Database on Shareholder Lawsuits. After eliminating cases with missing data and financial industries, the sample is reduced to 1,454 class actions for the time period 1996 (first year of data availability) to 2012 . As lawsuits are usually filed after the trigger event (Karpoff et al. 2008b), I include up to 5 years (if available) prior to the filing of the class action in my class action sample to capture the violation periods. My final sample includes 351 AAER firm-year observations. As reported in Table 7, my results hold for this sample and thus provide additional evidence in favor of $\mathrm{H} 1$.

\section{U.S. versus Non-U.S. Employment}

A concern with my measure of large employers is that it reflects a firm's total employees instead of a firm's U.S. employees. To address this concern, I obtain data on firms' U.S. and non-U.S. number of employees from Compustat Segments. As reporting the number of employees per geographical region is not required under SFAS 131 and has only been voluntarily reported as of 1999, the information is only available for a small subset of my original sample, i.e., 5,018 firm-years representing 1,217 firms. The descriptive statistics (untabulated) indicate that about 90 percent of the sample firms do not have employees outside 
of the U.S., suggesting that using firms' total number of employees is by and large reflective of firms' U.S. number of employees. In addition, I rerun model 1 but replace firm's number of employees by its U.S. and non-U.S. number of employees. As shown in Table 7, the coefficient on U.S. number of employees, but not on non-U.S. number of employees, is negative and significant, which is line with government's efforts to foster U.S. employment. However, given that firms that voluntarily report their number of employees in different geographic areas might not be representative of the overall sample, these results should be interpreted with caution.

\section{Partisanship of Presidential Administration}

I also investigate whether the preference for large employers is dependent on an administration's partisanship. In unreported tests, I find that the partisanship of the president does not affect the likelihood of enforcement against large employers.

\section{CONCLUSIONS}

The SEC has been criticized for its failure to detect several accounting fraud scandals in the last decade. A growing literature in accounting examines the reasons for such failure by studying the SEC's choice of enforcement targets. Studies in this growing literature find that the SEC's resource constraints as well as political pressure as a result of firms' political connections on the SEC affect the agency's choice of enforcement targets. Economists, however, have long argued that regulatory agencies such as the SEC are influenced by the president and Congress ("government") who respond to both voters' and special interests by adjusting their political decisions accordingly. As voters' political support is largely affected by the employment conditions, the government has long promoted large employers. In addition, the SEC's enforcement actions can have devastating consequences for firms and therefore employment. Thus, I investigate whether the SEC, as a consequence of government influence, reduces its 
enforcement actions for large employers. My results indicate that large employers are less likely to face an SEC enforcement action, after controlling for firm size, accounting quality, distance to SEC office, and political contributions, among other factors. I further exploit the variation in government's sensitivity to voters' interests to provide more robust evidence that large employers face less SEC enforcement actions due to government preferences for these firms. I find that the lower likelihood of SEC enforcement actions against large employers is more pronounced in presidential election years if they are headquartered in politically important states. I also find that firms that employ a larger proportion of a congressional district's total workforce are less likely to be subject to an SEC enforcement action if they are headquartered in districts with a high unemployment rate and a congressman serving on a committee that oversees the SEC.

The main limitation of my study is that AAERs represent the end product of SEC enforcement as opposed to the initial investigations. Thus, I cannot conclusively state or test at which exact stage of the SEC enforcement process political influence impacts the enforcement process. However, I find evidence that large employers receive fewer comment letters, suggesting that the SEC allocates fewer resources to reviews of large employers.

Overall, my results indicate that voters' interests drive political influence on the SEC and that the SEC incorporates such influence in its enforcement actions, independent of firms' lobbying for their special interests. Future research could explore other types of firms that the government has preferences for and the costs and benefits arising out of this preferential treatment in greater detail. 


\section{REFERENCES}

Adams, W., and J. W. Brock. 1986. Corporate power and economic sabotage. Journal of Economic Issues 20 (4):919-940.

Adams, W., and J. W. Brock. 1987a. Bigness and social efficiency: a case study of the US auto industry. In Corporations and Society, edited by A. S. Miller and W. Samuels. Westport, Conn.: Greenwood Press.

Adams, W., and J. W. Brock. 1987b. Corporate Size and the Bailout Factor. Journal of Economic Issues 21 (1):61-85.

Adams, W., and J. W. Brock. 2004. The Bigness Complex: Industry, Labor, and Government in the American Economy: Stanford University Press.

Alesina, A., R. Baqir, and W. Easterly. 2000. Redistributive public employment. Journal of Urban Economics 48 (2):219-241.

Alesina, A., and G. Tabellini. 2007. Bureaucrats or politicians? Part I: a single policy task. The American Economic Review 97 (1):169-179.

Armstrong, C. S., A. D. Jagolinzer, and D. F. Larcker. 2010. Chief executive officer equity incentives and accounting irregularities. Journal of Accounting Research 48 (2):225-271.

Barnes, P. 2009. Taxpayers Have \$80.3B Invested in Detroit. Available at: http://archive.is/3G13v (last access cited 11/06/2013).

Beneish, M. D. 1997. Detecting GAAP violation: Implications for assessing earnings management among firms with extreme financial performance. Journal of Accounting and Public Policy 16 (3):271-309.

Blau, B. M., T. J. Brough, and D. W. Thomas. 2013. Corporate lobbying, political connections, and the bailout of banks. Journal of Banking \& Finance 37 (8):3007-3017.

Brams, S. J., and M. D. Davis. 1974. The 3/2's rule in presidential campaigning. The American Political Science Review:113-134.

Brazel, J. F., K. L. Jones, and M. F. Zimbelman. 2009. Using nonfinancial measures to assess fraud risk. Journal of Accounting Research 47 (5):1135-1166.

Brown, C. O., and I. S. Dinc. 2005. The politics of bank failures: Evidence from emerging markets. The Quarterly Journal of Economics 120 (4):1413-1444.

Cassell, C. A., L. M. Dreher, and L. A. Myers. 2013. Reviewing the SEC's review process: 10-K comment letters and the cost of remediation. The Accounting Review 88 (6):1875-1908.

Cebula, R. J., C. M. Duquette, and F. G. Mixon Jr. 2013. Battleground states and voter participation in US presidential elections: an empirical test. Applied Economics 45 (26):3795-3799.

Christie, A. A., M. D. Kennelley, J. W. King, and T. F. Schaefer. 1984. Testing for incremental information content in the presence of collinearity. Journal of Accounting and Economics $6(3): 205-217$.

Correia, M. 2014. Political connections and SEC enforcement. Journal of Accounting and Economics.

CRP. 2013. Center for Responsive Politics. Available at: http: www.OpenSecrets.org/lobby/ (last access 11/12/2013).

Dechow, P. M., and I. D. Dichev. 2002. The quality of accruals and earnings: The role of accrual estimation errors. The Accounting Review 77 (s-1):35-59.

Dechow, P. M., W. Ge, C. R. Larson, and R. G. Sloan. 2011. Predicting Material Accounting Misstatements. Contemporary Accounting Research 28 (1):17-82. 
Dechow, P. M., R. G. Sloan, and A. P. Sweeney. 1995. Detecting Earnings Management. The Accounting Review 70 (2):193-225.

Dechow, P. M., R. G. Sloan, and A. P. Sweeney. 1996. Causes and consequences of earnings manipulation: An analysis of firms subject to enforcement actions by the SEC. Contemporary Accounting Research 13 (1):1-36.

Defond, M. L. 1992. The association between changes in client firm agency costs and auditor switching. Auditing: A Journal of Practice \& Theory 11 (1):16-31.

Dehejia, R. H., and S. Wahba. 2002. Propensity score-matching methods for nonexperimental causal studies. Review of Economics and statistics 84 (1):151-161.

Ettredge, M. L., L. Sun, P. Lee, and A. A. Anandarajan. 2008. Is earnings fraud associated with high deferred tax and/or book minus tax levels? Auditing: A Journal of Practice \& Theory 27 (1):1-33.

Feroz, E., K. J. Park, and V. Pastena. 1991. The financial and market effects of the SEC's accounting and auditing enforcement releases. Journal of Accounting Research 29:107142.

GAO. 2009. Securities and Exchange Commission - Greater attention needed to enhance communication and utilization of resources in the Division of Enforcement. Available at http://www.gao.gov/assets/290/288156.pdf (last access 2/14/2015).

GAO. 2013. Securities and Exchange Commission - Improving personnel management is critical for agency's effectiveness. Available at: http://www.gao.gov/assets/660/655989.pdf (last access $2 / 15 / 2015)$.

Garcia, D., and Ø. Norli. 2012. Geographic dispersion and stock returns. Journal of Financial Economics 106 (3):547-565.

Gartzke, E., and J. M. Wrighton. 1998. Thinking globally or acting locally? Determinants of the GATT vote in Congress. Legislative Studies Quarterly:33-55.

Goodman, S., and G. H. Kramer. 1975. Comment on Arcelus and Meltzer, the effect of aggregate economic conditions on congressional elections. American Political Science Review 69 (04):1255-1265.

Gordon, S. C., and C. Hafer. 2005. Flexing muscle: Corporate political expenditures as signals to the bureaucracy. American Political Science Review 99 (02):245-261.

Grier, K. B., M. McDonald, and R. D. Tollison. 1995. Electoral politics and the executive veto: A predictive theory. Economic Inquiry 33 (3):427-440.

Hennes, K. M., A. J. Leone, and B. P. Miller. 2008. The importance of distinguishing errors from irregularities in restatement research: The case of restatements and CEO/CFO turnover. The Accounting Review 83 (6):1487-1519.

Henriques, D. B. 2009. At Madoff Hearing, lawmakers lay into SEC. The New York Times. Available at http://www.nytimes.com/2009/02/05/business/05madoff.html?_r=0 (last access 7/24/2014).

Hibbing, J. R., and J. R. Alford. 1981. The electoral impact of economic conditions: who is held responsible? American Journal of Political Science 25 (3):423-439.

Hibbs, D. A. 2006. Voting and the Macroeconomy. In The Oxford Handbook of Political Economy, edited by B. R. Weingast and D. A. Wittman: Oxford University Press, 565586.

Hirsch, B. T., and D. A. Macpherson. 2003. Union Membership and Coverage Database from the Current Population Survey: Note. Industrial and Labor Relations Review 56 (2):349-354. 
Holbrook, T. M. 1991. Presidential elections in space and time. American Journal of Political Science:91-109.

Hunter, W. J., and M. A. Nelson. 1995. Tax enforcement: A public choice perspective. Public Choice 82 (1-2):53-67.

Jones, J. J. 1991. Earnings Management during Import Relief Investigations. Journal of Accounting Research 29 (2):193-228.

Kalt, J. P., and M. A. Zupan. 1984. Capture and ideology in the economic theory of politics. The American Economic Review 74 (3):279-300.

Karpoff, J. M., D. S. Lee, and G. S. Martin. 2007. The legal penalties for financial misrepresentation.

Karpoff, J. M., D. S. Lee, and G. S. Martin. 2008a. The consequences to managers for financial misrepresentation. Journal of Financial Economics 88 (2):193-215.

Karpoff, J. M., D. S. Lee, and G. S. Martin. 2008b. The cost to firms of cooking the books. Journal of Financial and Quantitative Analysis 43 (3):581-612.

Kau, J. B., D. Keenan, and P. H. Rubin. 1982. A general equilibrium model of congressional voting. The Quarterly Journal of Economics 97 (2):271-293.

Kedia, S., and S. Rajgopal. 2011. Do the SEC's enforcement preferences affect corporate misconduct? Journal of Accounting and Economics 51 (3):259-278.

Kido, N., R. Petacchi, and J. Weber. 2012. The influence of elections on the accounting choices of governmental entities. Journal of Accounting Research 50 (2):443-476.

Kiewiet, D. R., and M. D. McCubbins. 1985. Congressional appropriations and the electoral connection. The Journal of Politics 47 (01):59-82.

Kinder, D. R., and D. R. Kiewiet. 1979. Economic discontent and political behavior: The role of personal grievances and collective economic judgments in congressional voting. American Journal of Political Science 23 (3):495-527.

Kinder, D. R., and D. R. Kiewiet. 1981. Sociotropic politics: The American case. British Journal of Political Science 11 (2):129-161.

Kramer, G. H. 1971. Short-term fluctuations in US voting behavior: 1896-1964. American Political Science Review 65 (1):131-143.

Levitt, A., and P. Dwyer. 2003. Take on the street: how to fight for your financial future: Vintage Books.

MacRae, C. D. 1977. A political model of the business cycle. The Journal of Political Economy 85 (2):239-263.

McCarty, N. M. 2000. Presidential pork: Executive veto power and distributive politics. American Political Science Review:117-129.

Mebane, W. R., and G. J. Wawro. 1993. Pork Barrel Politics in Presidential Elections. Paper read at Annual Meeting of the Midwest Political Science Association.

Mian, A., A. Sufi, and F. Trebbi. 2010. The Political Economy of the US Mortgage Default Crisis. The American Economic Review 100 (5):1967-1998.

Milyo, J., D. Primo, and T. Groseclose. 2000. Corporate PAC campaign contributions in perspective. Business and Politics 2 (1):75-88.

Mixon, F. G. 1995. Public choice and the EPA: Empirical evidence on carbon emissions violations. Public Choice 83 (1-2):127-137.

Noll, R. G. 1971. Reforming regulation: An evaluation of the Ash Council proposals. Vol. 837: Brookings Institution Washington, DC.

Nordhaus, W. D. 1975. The political business cycle. Review of Economic Studies 42 (2):169-190. 
Orol, R. 2013. Enforcer in chief: A conversation with Robert Khuzami. Available at: http://www.thedeal.com/content/regulatory/enforcer-in-chief-a-conversation-with-robertkhuzami.php (last access 2/5/2015).

Peltzman, S. 1976. Toward a more general Theory of Regulation. Journal of Law and Economics 19:211-240.

Peltzman, S. 1984. Constituent interest and congressional voting. Journal of Law and Economics 27:181-210.

Peltzman, S. 1985. An Economic Interpretation of the History of Congressional Voting in the Twentieth Century. The American Economic Review.

Peltzman, S. 1992. Voters as fiscal conservatives. The Quarterly Journal of Economics 107 (2):327-361.

Plumlee, M., and T. L. Yohn. 2010. An analysis of the underlying causes attributed to restatements. Accounting Horizons 24 (1):41-64.

Potrafke, N. 2012. Political cycles and economic performance in OECD countries: Empirical evidence from 1951-2006. Public Choice 150 (1-2):155-179.

Price, R. A., N. Y. Sharp, and D. A. Wood. 2011. Detecting and predicting accounting irregularities: A comparison of commercial and academic risk measures. Accounting Horizons 25 (4):755-780.

Ramanna, K., and S. Roychowdhury. 2010. Elections and discretionary accruals: Evidence from 2004. Journal of Accounting Research 48 (2):445-475.

Rosenbaum, P. R. 2002. Observational Studies. Vol. 2nd ed. Berlin: Springer Series in Statistics.

SEC. 2005. Speech by SEC Commissioner Paul S. Atkins: Remarks before the American Institute of Certified Public Accountants. Available at:

http://www.sec.gov/news/speech/spch120505psa.htm (last access 2/20/2015).

SEC. 2013a. Current SEC Commissioners. Available at:

http://www.sec.gov/about/commissioner.shtml (last access 10/15/2013).

SEC. 2013b. Securities and Exchange Commission - Division of Enforcement - Enforcement

Manual. Available at: http://www.sec.gov/divisions/enforce/enforcementmanual.pdf (last access 2/9/2015).

SEC. 2013c. What we do. Available at: http://www.sec.gov/about/whatwedo.shtml (last access 10/03/2013).

SEC. 2014a. SEC announces 2014 examination priorities. Available at:

http://www.sec.gov/News/PressRelease/Detail/PressRelease/1370540599051\#.VNoTWE $\mathrm{fF} 8 \mathrm{nU}$ (last access 2/10/2015).

SEC. 2014b. Testimony on "Oversight of the SEC's Agenda, Operations and FY 2015 Budget

Request”. Available at:

http://www.sec.gov/News/Testimony/Detail/Testimony/1370541674457\#.VNzluUfF8nU (last access 2/12/2015).

SEC. 2014c. Three key pressure points in the current enforcement environment - Chair Mary Jo

White. Available at:

http://www.sec.gov/News/Speech/Detail/Speech/1370541858285\#_ftn1 (last access 2/5/2015).

Stigler, G. J. 1971. The Theory of Economic Regulation. The Bell Journal of Economics and Management Science 2 (1):3-21. 
Waas, M. 2012. Insight: How Allen Stanford kept the SEC at bay. Reuters. Available at: http://www.reuters.com/article/2012/01/26/us-sec-stanford-idUSTRE80P22R20120126 (last access 7/24/2014).

Watts, R. L., and J. L. Zimmerman. 1978. Towards a positive theory of the determination of accounting standards. The Accounting Review 53 (1):112-134.

Weingast, B. R. 1984. The congressional-bureaucratic system: a principal agent perspective (with applications to the SEC). Public Choice 44 (1):147-191.

Wooldridge, J. M. 2002. Econometric Analysis of Cross Section and Panel Data. 2nd ed. Boston: The MIT Press.

Young, M., M. Reksulak, and W. F. Shughart. 2001. The political economy of the IRS. Economics \& Politics 13 (2):201-220.

$\mathrm{Yu}, \mathrm{F}$., and X. Yu. 2011. Corporate lobbying and fraud detection. Journal of Financial and Quantitative Analysis 46 (6):1865. 
Appendix A: Top 10 most important states per presidential election ${ }^{\mathrm{a}}$

\begin{tabular}{|c|c|c|}
\hline \multicolumn{3}{|c|}{ Top 10, 1984} \\
\hline Rank & State & Score \\
\hline 1 & $\mathrm{MN}$ & 85.00 \\
\hline 2 & RI & 8.54 \\
\hline 3 & MA & 5.83 \\
\hline 4 & MD & 3.48 \\
\hline 5 & HI & 3.37 \\
\hline 6 & IA & 2.62 \\
\hline 7 & VT & 2.39 \\
\hline 8 & PA & 2.24 \\
\hline 9 & NY & 2.11 \\
\hline 10 & WV & 2.07 \\
\hline \multicolumn{3}{|c|}{ Top 10, 1996} \\
\hline Rank & State & Score \\
\hline 1 & $\mathrm{NV}$ & 13.47 \\
\hline 2 & KY & 9.56 \\
\hline 3 & GA & 7.67 \\
\hline 4 & $\mathrm{CO}$ & 6.16 \\
\hline 5 & VA & 4.38 \\
\hline 6 & SD & 4.26 \\
\hline 7 & $\mathrm{AZ}$ & 4.08 \\
\hline 8 & MT & 4.07 \\
\hline 9 & $\mathrm{TN}$ & 3.84 \\
\hline 10 & ND & 2.63 \\
\hline \multicolumn{3}{|c|}{ Top 10, 2008} \\
\hline Rank & State & Score \\
\hline 1 & MO & 86.85 \\
\hline 2 & $\mathrm{NC}$ & 32.60 \\
\hline 3 & IN & 11.94 \\
\hline 4 & MT & 8.33 \\
\hline 5 & FL & 3.52 \\
\hline 6 & ND & 3.38 \\
\hline 7 & SD & 2.88 \\
\hline 8 & $\mathrm{OH}$ & 2.35 \\
\hline 9 & GA & 2.26 \\
\hline 10 & $\mathrm{NH}$ & 1.80 \\
\hline
\end{tabular}

\begin{tabular}{ccc}
\hline \multicolumn{3}{c}{ Top 10, 1988 } \\
\hline Rank & State & Score \\
\hline 1 & VT & 5.57 \\
2 & WA & 5.35 \\
3 & IL & 4.01 \\
4 & PA & 3.78 \\
5 & MD & 3.19 \\
6 & NM & 3.07 \\
7 & MT & 2.96 \\
8 & WV & 2.57 \\
9 & WI & 2.20 \\
10 & NY & 2.15 \\
\hline
\end{tabular}

\begin{tabular}{ccc}
\hline \multicolumn{3}{c}{ Top 10, 1992 } \\
\hline Rank & State & Score \\
\hline 1 & GA & 11.61 \\
2 & NC & 8.32 \\
3 & NH & 7.47 \\
4 & NV & 3.69 \\
5 & MT & 3.57 \\
6 & AZ & 3.37 \\
7 & WY & 3.28 \\
8 & SD & 3.11 \\
9 & FL & 3.04 \\
10 & OH & 2.84 \\
\hline
\end{tabular}

\begin{tabular}{ccc}
\hline \multicolumn{3}{c}{ Top 10, 2000 } \\
\hline Rank & State & Score \\
\hline 1 & FL & 1115.40 \\
2 & NM & 327.31 \\
3 & WI & 46.17 \\
4 & IA & 40.47 \\
5 & OR & 24.79 \\
6 & NH & 13.29 \\
7 & NV & 4.43 \\
8 & MN & 4.09 \\
9 & MO & 3.35 \\
10 & TN & 3.28 \\
\hline
\end{tabular}

\begin{tabular}{ccc}
\hline \multicolumn{3}{c}{ Top 10, 2004 } \\
\hline Rank & State & Score \\
\hline 1 & WI & 18.56 \\
2 & NM & 13.34 \\
3 & IA & 11.38 \\
4 & NH & 9.57 \\
5 & NV & 5.09 \\
6 & PA & 3.61 \\
7 & OH & 3.21 \\
8 & HI & 2.36 \\
9 & DE & 2.32 \\
10 & OR & 2.28
\end{tabular}

\begin{tabular}{ccc}
\hline \multicolumn{3}{c}{ Top 10, 2012 } \\
\hline Rank & State & Score \\
\hline 1 & FL & 11.95 \\
2 & NC & 4.99 \\
3 & OH & 3.32 \\
4 & NH & 3.09 \\
5 & NV & 2.71 \\
6 & VA & 2.67 \\
7 & AK & 2.19 \\
8 & CO & 2.00 \\
9 & IA & 1.98 \\
10 & PA & 1.95 \\
\hline
\end{tabular}

Notes to Appendix A

${ }^{a}$ Appendix A includes an overview of the top ten most important states per presidential election over the period 1982-2012. I follow the methodology of Cebula et al. (2013) and express the political importance of a state by dividing the number of Electoral College votes at stake by the margin of victory for the winning candidate, denoted "Score". The states are then ranked in descending order for each U.S. presidential election based on that score. 


\section{Appendix B: Overview of variables}

\begin{tabular}{|c|c|}
\hline Variable & Definition \\
\hline \multicolumn{2}{|l|}{ Dependent Variables } \\
\hline AAER Dummy & $\begin{array}{l}1 \text { in the years a misstatement occurred as reported in the Accounting and Auditing Enforcement Releases, and } \\
\text { zero otherwise. }\end{array}$ \\
\hline Number of Comment Letters & Number of comment letters a firm has either received or sent to the SEC. \\
\hline Comment Letter Dummy & 1 in the years a firm has received a comment letter from the SEC, and zero otherwise. \\
\hline \multicolumn{2}{|l|}{ Variables of interest } \\
\hline Log Employees & Natural logarithm of a firm's total employees, i.e., Compustat item: EMP. \\
\hline (Non-)U.S. Log Employees & Natural logarithm of a firm's (non-)U.S. employees (Compustat Segments item: EMPS). \\
\hline Local Employees & $\begin{array}{l}\text { Local employees are a firm's workforce in proportion to the congressional district's total workforce. To } \\
\text { measure a firm's share of total employment per district, I obtain data from Garcia and Norli (2012) for the } \\
\text { time period 1994-2008 who developed a method to identify the location of firms' operations. In particular, } \\
\text { they count the number of times firms' headquarter state name occurs relative to all other state names in firms' } \\
\text { 10-Ks; in particular, in sections "Item 1: Business", "Item 2: Properties", "Item 6: Consolidated Financial } \\
\text { Data", and "Item 7: Management's Discussion and Analysis". I also obtain data from the U.S. Census Bureau } \\
\text { on the total workforce per congressional district and state and scale firms' adjusted number of employees by } \\
\text { the workforce per congressional district or state. }\end{array}$ \\
\hline Election Year & $\begin{array}{l}1 \text { in all presidential election years (i.e., 1984, 1988, 1992, 1996, 2000, 2004, } 2008 \text { and 2012), and zero } \\
\text { otherwise. }\end{array}$ \\
\hline Important State & $\begin{array}{l}1 \text { for the top ten most important states for each U.S. presidential election, and zero otherwise. The top ten most } \\
\text { important states are defined by following the methodology of Cebula et al. (2013) who express the political } \\
\text { importance of a state by dividing the number of Electoral College votes at stake by the margin of victory for } \\
\text { the winning candidate. The states are then ranked in descending order for each U.S. presidential election. }\end{array}$ \\
\hline SEC Committee & $\begin{array}{l}1 \text { if a firm's headquarters are located in a congressional district with a member of the House who serves on the } \\
\text { House Appropriations, Banking or Commerce committee, and zero otherwise. To construct this variable data } \\
\text { is obtained from Charles Stewart's Congressional Data webpage for all members of the House for the time } \\
\text { period 1982-2012 and every firm is matched to a specific district based on its zip code as reported in } \\
\text { Compustat. }\end{array}$ \\
\hline High Unemployment District & $\begin{array}{l}1 \text { if a district's unemployment rate is larger than the average unemployment rate across all districts per state } \\
\text { and year, and zero otherwise. I obtain data on congressional districts' unemployment rates from the U.S. } \\
\text { Census Bureau. }\end{array}$ \\
\hline \multicolumn{2}{|l|}{ Control Variables } \\
\hline F-score 1 & $\begin{array}{l}\text { Predicted value }=-7.893+0.79 * \text { RSST accruals }+2.518 * \text { Change in receivables }+1.191 * \text { Change in } \\
\text { inventory }+1.979 * \% \text { Soft assets }+0.171 * \text { Change in cash sales }+-0.932 * \text { Change in ROA }+1.029 * \text { Actual } \\
\text { issuance. Based on this predicted value the probability is calculated as } \mathrm{e}^{\text {(predicted value })} /\left(1+\mathrm{e}^{(\text {predicted value })}\right) \text {. To arrive } \\
\text { at the F-score the probability is divided by the unconditional probability, i.e., misstating firm-years/(non- } \\
\text { misstating firm-years + misstating firm years). For more details see Dechow et al. }(2011) .\end{array}$ \\
\hline F-score 2 & $\begin{array}{l}\text { Predicted value }=-8.252+0.665 * \text { RSST accruals }+2.457 * \text { Change in receivables }+1.393 * \text { Change in } \\
\text { inventory }+2.011 * \% \text { Soft assets }+0.159 * \text { Change in cash sales }+-1.029 * \text { Change in ROA }+0.983 * \text { Actual } \\
\text { issuance }+-0.15 * \text { Abnormal change in employees }+0.419 * \text { Existence of operating leases. Based on this } \\
\text { predicted value the probability is calculated as } \mathrm{e}^{\text {(predicted value })} /\left(1+\mathrm{e}^{\text {(predicted value) }}\right) \text {. To arrive at the F-score the } \\
\text { probability is divided by the unconditional probability, i.e., misstating firm-years/(non-misstating firm-years }+ \\
\text { misstating firm years). For more details see Dechow et al. }(2011) .\end{array}$ \\
\hline F-score 3 & $\begin{array}{l}\text { Predicted value }=-7.966+0.909 * \text { RSST accruals }+1.731 * \text { Change in receivables }+1.447 * \text { Change in } \\
\text { inventory }+2.265 * \% \text { Soft assets }+0.160 * \text { Change in cash sales }+-1.455 * \text { Change in ROA }+0.651 * \text { Actual } \\
\text { issuance }+-0.121 * \text { Abnormal change in employees }+0.345 * \text { Existence of operating leases }+0.082 * \text { Market- } \\
\text { adjusted stock return }+0.098 * \text { lagged market-adjusted stock return. Based on this predicted value the } \\
\text { probability is calculated as } \mathrm{e}^{(\text {predicted value) }} /\left(1+\mathrm{e}^{(\text {(predicted value) }) . ~ T o ~ a r r i v e ~ a t ~ t h e ~ F-s c o r e ~ t h e ~ p r o b a b i l i t y ~ i s ~ d i v i d e d ~ b y ~}\right. \\
\text { the unconditional probability, i.e., misstating firm-years/(non-misstating firm-years }+ \text { misstating firm years). } \\
\text { For more details see Dechow et al. }(2011) .\end{array}$ \\
\hline Mod. Jones Dis. Acc. & $\begin{array}{l}\text { Discretionary accruals using the following modified Jones model as in Dechow et al. (2011): } \Delta W C_{t}=\beta_{0}+ \\
\left.\beta_{1}\left(1 / A_{t-1}\right)+\beta_{2} \frac{\Delta S_{t}-\Delta R e c_{t}}{A_{t-1}}+\beta_{3} \frac{\Delta P P E_{t}}{A_{t-1}}+e_{t}\right) \text { where } \Delta \mathrm{WC}_{\mathrm{t}}=\Delta \mathrm{AR}_{\mathrm{t}}+\Delta \mathrm{Inventory}_{\mathrm{t}}-\Delta \mathrm{AP}_{\mathrm{t}}-\Delta \mathrm{TP}_{\mathrm{t}}+\Delta \mathrm{other} \\
\text { Assets (net) } \mathrm{t} \text {. AR is accounts receivable, } \mathrm{AP} \text { is accounts payable, TP is taxes payable. } \mathrm{S} \text { is sales, Rec accounts } \\
\text { receivables, } \mathrm{A}_{\mathrm{t}-1} \text { beginning of the year assets and PPE is property, plant and equipment. The unsigned } \\
\text { estimated residuals are my proxy for discretionary accruals. }\end{array}$ \\
\hline DD Dis. Acc. & $\begin{array}{l}\text { Discretionary accruals according to Dechow and Dichev (2002), using the following OLS model: } \Delta W C_{t}= \\
\beta_{0}+\beta_{1}\left(1 / A_{t-1}\right)+\beta_{2} C F O_{t-1}+\beta_{3} C F O_{t}+\beta_{4} C F O_{t+1}+e_{t} \text { where } \triangle \mathrm{WCt} \text { is defined the same as for the } \\
\text { modified Jones model and CFO is cash flow from operations. The unsigned estimated residuals are my proxy } \\
\text { for discretionary accruals. }\end{array}$ \\
\hline
\end{tabular}




\begin{tabular}{|c|c|}
\hline Restatement & $\begin{array}{l}1 \text { in the years a restatement has been released by firms, and zero otherwise. Restatements include intentional } \\
\text { as well as unintentional misstatements as per the criteria of Hennes et al. (2008). }\end{array}$ \\
\hline Proximate 100 & $\begin{array}{l}1 \text { if a firm's headquarters is located within } 100 \mathrm{~km} \text { distance to the SEC office, i.e., SEC offices in Washington, } \\
\text { DC, New York City, NY, Miami, FL, Chicago, IL, Denver, CO, and Los Angeles, CA, and zero otherwise. } \\
\text { For more details see Kedia and Rajgopal (2011). }\end{array}$ \\
\hline PAC Contributions & A firm's PAC contributions as reported in the FEC dataset scaled by total average assets. \\
\hline Lobbying Exp & A firm's lobbying expenditures as reported in the CRP dataset scaled by total average assets. \\
\hline Union & $\begin{array}{l}\text { Percentage of employees who are union members per four-digit SIC code as reported in the Union } \\
\text { Membership and Coverage Database maintained by Hirsch and Macpherson (2003). }\end{array}$ \\
\hline Log Analysts Following & $\begin{array}{l}\text { Natural logarithm of the number of analysts issuing annual earnings forecasts for firms covered by IBES. Set } \\
\text { equal to zero if the firm is not covered by IBES. }\end{array}$ \\
\hline Fortune 500 & 1 if the firm is covered in the Fortune 500 index as reported in Compustat, zero otherwise. \\
\hline ROA & Two-digit SIC code median-adjusted return on assets, i.e., Compustat item: IB / Total average assets. \\
\hline Big 4 & 1 if a firm's auditor is a Big 4 auditor, zero otherwise. \\
\hline Market-to-book & $\begin{array}{l}\text { Firm's market value scaled by firm's book value, i.e., (Compustat item: CSHO * Compustat item: PRCC) / } \\
\text { Compustat item: CEQ. }\end{array}$ \\
\hline Leverage & Firm's long-term debt scaled by firm's total average assets, i.e., Compustat item: DLTT / Total average assets. \\
\hline Log Firm Age & Natural logarithm of a firm's age; based on first time appearance in Compustat. \\
\hline Log Assets & Natural logarithm of a firm's total assets, i.e., Compustat item: AT. \\
\hline SEC Chairman & $\begin{array}{l}\text { Fixed effects for the tenure of each SEC Chairman as reported on the SEC homepage } \\
\text { (http://www.sec.gov/about/sechistoricalsummary.htm). }\end{array}$ \\
\hline U.S. President & Fixed effects for the tenure of each U.S. President. \\
\hline
\end{tabular}

\section{Appendix C: Measures of accounting quality}

To investigate whether large employers have a better accounting quality, I run the following ordinary least squares regression model and logistic regression model, respectively, where subscript $i$ represents the firm and $t$ the year:

$$
\text { Accounting Quality }_{i t}=\beta_{0}+\beta_{1} \text { Log Employees }_{i t}+\sum_{n} \beta_{n} \text { Controls }_{i t}+e_{i t}
$$

ACCOUNTING QUALITY is measured using six different proxies. In particular, in three of the six models I use the three different types of F-scores as developed by Dechow et al. (2011). Recall that the F-score can be used as a red flag of the likelihood of earnings misstatement (Dechow et al. 2011). In addition, I use the modified Jones model (Dechow et al. 1995) and the Dechow and Dichev (2002) discretionary accrual model to measure accounting quality. To determine discretionary accruals, I first estimate the following modified Jones model (1991) cross-sectionally as in Dechow et al. (2011) for every two-digit industry-year $t$ with at least ten observations per industry-year:

$\Delta W C_{t}=\beta_{0}+\beta_{1}\left(1 / A_{t-1}\right)+\beta_{2} \frac{\Delta S_{t}-\Delta R e c_{t}}{A_{t-1}}+\beta_{3} \frac{\Delta P P E_{t}}{A_{t-1}}+e_{t}$

where $\Delta W C_{t}=\Delta A R_{t}+\Delta$ Inventory $_{t}-\Delta A P_{t}-\Delta T P_{t}+\Delta$ Other Assets (net). $A R_{t}$ is accounts receivable, $A P_{t}$ is accounts payable, $T P_{t}$ is taxes payable. $S_{t}$ is sales, $R e c_{t}$ accounts receivables, $A_{t-}$ ${ }_{l}$ beginning of the year assets, and $P P E_{t}$ is property, plant and equipment. The estimated absolute residuals are my proxy for discretionary accruals, denoted MOD. JONES DIS. ACC.

To determine the discretionary accruals according to Dechow and Dichev (2002), I estimate the following ordinary least squares model cross-sectionally for every two-digit industry-year $t$ with at least ten observations per industry-year:

$\Delta W C_{t}=\beta_{0}+\beta_{1}\left(1 / A_{t-1}\right)+\beta_{2} C_{F O} O_{t-1}+\beta_{3} C F O_{t}+\beta_{4} C F O_{t+1}+e_{t}$

where $\triangle W C_{t}$ is defined as above and $C F O$ is cash flow from operations. The estimated absolute residuals are my proxy for discretionary accruals, denoted DD DIS. ACC. 
As a final measure of firms' accounting quality, I obtain all restatements from the GAO Financial Statement Restatement Database, which covers the time period 1997-2006. I run the aforementioned model as a logistic regression model where ACCOUNTING QUALITY is measured using restatements as an indicator variable that is equal to one in the years a restatement has been released by firms. Prior research suggests that a substantial number of restatements are due to unintentional errors rather than intentional misstatements (Hennes, Leone, and Miller 2008; Plumlee and Yohn 2010). I include both intentional as well as unintentional errors in my sample due to two reasons. First, restatements are an important trigger event for SEC enforcement actions (Dechow et al. 2011; Kedia and Rajgopal 2011). As a consequence, firms that do not enjoy preferential treatment by the SEC might exercise more care in the preparation of their financial statements making it less likely that these firms make unintentional errors as well as intentional misstatements. Second, a large number of restatements due to intentional misstatements are initiated by regulatory action (Dechow et al. 2011). Thus, firms that enjoy preferential treatment by the SEC and thus are likely to face fewer enforcement actions are potentially less likely to be required to restate their financials due to intentional misstatements.

Table 1: Sample selection of Accounting and Auditing Enforcement Releases ${ }^{\mathrm{a}}$

\begin{tabular}{|c|c|c|}
\hline & $\begin{array}{c}\text { Number of misstated firm } \\
\text { years }\end{array}$ & Number of distinct firms \\
\hline AAER No. 1-No. 3180 from May 1982 to August 2012 & 1,838 & 789 \\
\hline Less: AAER firms without CIK & $(251)$ & $(133)$ \\
\hline Less: Misstatements that cannot be linked to specific reporting periods & $(84)$ & $(44)$ \\
\hline Less: AAER firms without CRSP and Compustat match & (331) & (123) \\
\hline Less: AAER firms with missing data & $(452)$ & (174) \\
\hline Less: AAER firms in financial industry & $(26)$ & (9) \\
\hline Final AAER sample & 694 & 306 \\
\hline
\end{tabular}

\footnotetext{
Notes to Table 1:
}

${ }^{a}$ Table 1 includes an overview of the AAER sample selection. I obtain the AAER sample from Dechow et al. (2011). Their dataset consists of 3,403 SEC AAERs or 1,297 firm misstatement events issued between May 17th 1982 and August 31th 2012. The 1,297 firm misstatement events represent 1,838 misstated firm-years against 789 distinct firms. After dropping 251 (133) AAER firm years (firms) without CIK, 84 (44) AAER firm years (firms) with misstatements that cannot be linked to a specific reporting period, 331 (123) AAER firm years (firms) that cannot be matched to CRSP and Compustat, 452 (174) AAER firm years (firms) with missing data for any of the variables used in the analyses, 26 (9) AAER firm years (firms) that occur in financial industries, i.e., two-digit SIC codes 60-69, I arrive at my final AAER sample of 694 (306) AAER firm years (firms).

\section{Figure1: Timeline of an SEC enforcement action}

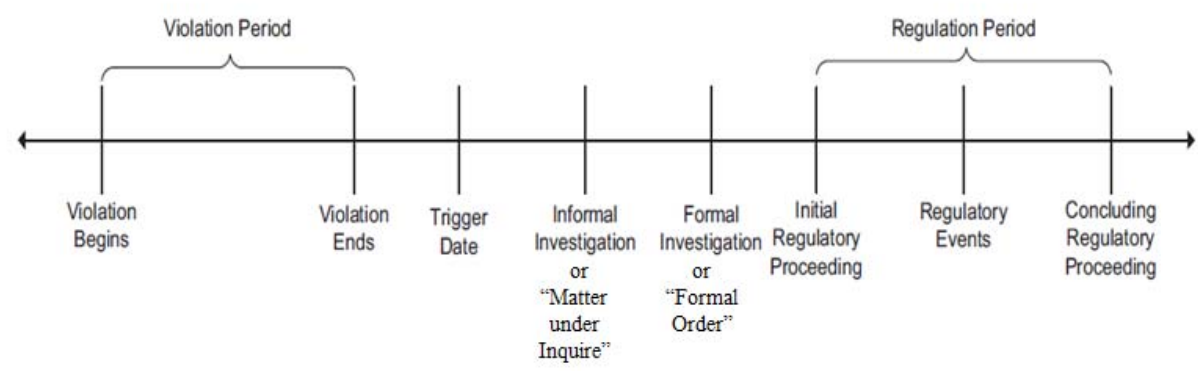


Table 2: Descriptive statistics

Panel A: Summary statistics for years 1982 to $2012^{\mathrm{a}}$

\begin{tabular}{ccccccccc}
\hline Variable & $\mathbf{N}$ & Mean & Std. & Min & $\mathbf{1}^{\text {st }}$ & Median & $\mathbf{3}^{\text {rd }}$ & Max $^{2.92}$ \\
\hline Employees & 93,207 & 6.823 & 18.524 & .003 & .179 & .837 & 3.992 & 127.5 \\
F-score 1 & 93,207 & 1 & .727 & .120 & .484 & .819 & 1.284 & 4.287 \\
F-score 2 & 93,207 & 1 & .758 & .107 & .464 & .810 & 1.230 & 4.419 \\
F-score 3 & 93,207 & 1 & .809 & .130 & .480 & .847 & 1.387 & 4.624 \\
DD Dis. Acc. & 93,207 & 0.062 & 0.070 & 0 & 0.016 & 0.038 & 0.079 & 0.334 \\
Mod. Jones Dis. Acc. & 93,207 & 0.056 & 0.061 & 0 & 0.014 & 0.035 & 0.074 & 0.292 \\
Proximate 100 & 93,207 & .313 & .464 & 0 & 0 & 0 & 1 & 1 \\
PAC Contribution Dummy & 93,207 & .274 & .446 & 0 & 0 & 0 & 1 & 1 \\
PAC Contributions & 93,207 & 14,646 & 211,891 & 0 & 0 & 0 & 570 & 291,268 \\
Lobbying Amount & 55,913 & 71,621 & 284,129 & 0 & 0 & 0 & 0 & $1,740,000$ \\
Union & 93,207 & 0.115 & 0.116 & 0 & 0.027 & 0.0755 & 0.162 & 0.499 \\
Analyst Following & 93,207 & 4.47 & 6.14 & 0 & 0 & 2 & 6 & 28 \\
ROA & 93,207 & -.057 & .228 & -1.16 & -.074 & 0 & .052 & .284 \\
Big 4 & 93,207 & .814 & .389 & 0 & 1 & 1 & 1 & 1 \\
Market-to-Book & 93,207 & 2.804 & 4.544 & -12.751 & 1.069 & 1.825 & 3.261 & 29.268 \\
Leverage & 93,207 & .179 & .199 & 0 & .003 & .119 & .292 & .898 \\
Firm Age & 93,207 & 14.92 & 14.08 & 2 & 5 & 10 & 20 & 71 \\
Assets & 93,207 & 1,808 & 5,790 & 2.12 & 32.79 & 140.98 & 738.16 & 41,959 \\
\hline
\end{tabular}

Notes to Table 2, Panel A:

${ }^{a}$ The table displays the summary statistics of the full sample for all variables over the period 1982-2012. See Appendix B for variable definitions.

\section{Panel B: Statistics for large vs. small employers ${ }^{\mathrm{b}}$}

\begin{tabular}{ccccc}
\hline Variable & $\mathbf{N}$ & Large employers (1) & Small employers (2) & Difference (1) - (2) \\
\hline Employees & 93,207 & 13.396 & 0.253 & $13.143^{* * *}$ \\
F-score 1 & 93,207 & 1.02 & 0.968 & $.052^{* * *}$ \\
F-score 2 & 93,207 & 1.03 & 0.972 & $.058^{* * *}$ \\
F-score 3 & 93,207 & 1.09 & 1.03 & $.060^{* * *}$ \\
DD Dis. Acc. & 93,207 & 0.034 & 0.010 & $0.024^{* * *}$ \\
Mod. Jones Dis. Acc. & 93,207 & 0.015 & 0.024 & -0.009 \\
Proximate 100 & 93,207 & 0.281 & 0.342 & $-.061^{* * *}$ \\
PAC Contribution Dummy & 93,207 & 0.392 & 0.157 & $0.235^{* * *}$ \\
PAC Contributions & 93,207 & 27,442 & 1,857 & $25,585^{* * *}$ \\
Lobbying Amount & 55,913 & 124,034 & 9,907 & $114,127^{* * *}$ \\
Union & 93,207 & 0.136 & 0.095 & $0.041^{* * *}$ \\
Analyst Following & 93,207 & 7.23 & -0.127 & $5.52^{* * *}$ \\
ROA & 93,207 & 0.012 & 0.704 & $.139^{* * *}$ \\
Big 4 & 93,207 & 0.925 & 3.10 & $.221^{* * *}$ \\
Market-to-Book & 93,207 & 2.51 & 0.132 & $-.59^{* * *}$ \\
Leverage & 93,207 & 0.226 & 10.61 & $.94^{* * *}$ \\
Firm Age & 93,207 & 19.23 & 132 & $8.62^{* * *}$ \\
Assets & 93,207 & 3,613 & $3,481^{* * *}$ \\
\hline
\end{tabular}

Notes to Table 2, Panel B:

${ }^{\mathrm{b}}$ The table displays average values of the variables over the period 1982-2012 for two groups of firms: (i) larger employers and (ii) smaller employers. I constructed these groups by splitting the sample at the median value of the variable log employees. The table also displays the differences between the means of these variables. ***,**, and * indicate the significance at the $1 \%, 5 \%$ and $10 \%$ level, respectively, of the difference between the means of larger as compared to smaller employers. See Appendix B for variable definitions. 
Panel C: Statistics for AAER vs. non-AAER firms ${ }^{c}$

\begin{tabular}{cccccc}
\hline Variable & $\mathbf{N}$ & AAER sample (1) & $\mathbf{N}$ & Non-AAER sample (2) & Difference (1) - (2) \\
\hline Employees & 694 & 12.35 & 92,513 & 6.783 & $5.567^{* * * *}$ \\
F-score 1 & 694 & 1.47 & 92,513 & 1 & $.47^{* * *}$ \\
F-score 2 & 694 & 1.51 & 92,513 & 1 & $.51^{* * *}$ \\
F-score 3 & 694 & 1.61 & 92,513 & 1.06 & $.55^{* * *}$ \\
DD Dis. Acc. & 694 & 0.077 & 92,513 & 0.062 & $0.015^{* * *}$ \\
Mod. Jones Dis. Acc. & 694 & 0.067 & 92,513 & 0.056 & $0.011^{* * *}$ \\
Proximate 100 & 694 & .369 & 92,513 & .312 & $.057^{* * *}$ \\
PAC Contribution Dummy & 694 & .412 & 92,513 & .273 & $0.13^{* * *}$ \\
PAC Contributions & 694 & 27,265 & 92,513 & 14,555 & $12,710^{*}$ \\
Lobbying Amount & 509 & 113,658 & 55,404 & 71,235 & $42,423^{* * *}$ \\
Union & 694 & 0.096 & 92,513 & 0.115 & $-0.019^{* * *}$ \\
Analyst Following & 694 & 7.51 & 92,513 & 4.45 & $3.06^{* * *}$ \\
ROA & 694 & -.029 & 92,513 & -.058 & $.029^{* * *}$ \\
Big 4 & 694 & .859 & 92,513 & .814 & $.044^{* * *}$ \\
Market-to-Book & 694 & 3.75 & 92,513 & 2.80 & $.954^{* * *}$ \\
Leverage & 694 & .188 & 92,513 & .179 & .009 \\
Firm Age & 694 & 13.87 & 92,513 & 14.93 & $-1.06^{* *}$ \\
Assets & 694 & 3,243 & 92,513 & 1,798 & $1,445^{* * *}$ \\
\hline
\end{tabular}

Notes to Table 2, Panel C:

${ }^{c}$ The table displays average values of the variables over the period 1982-2012 for two groups of firms: (i) the AAER sample, i.e., firms that received an AAER; and (ii) the non-AAER sample, i.e., firms that did not receive an AAER; and the differences between the means of these variables. ${ }^{* *}, * *$, and $*$ indicate the significance at the $1 \%, 5 \%$ and $10 \%$ level, respectively, of the difference between the means of the AAER sample as compared to the non-AAER sample. See Appendix B for variable definitions. 
Table 3: Test of hypothesis 1

Panel A: Logistic regression estimation of the probability of being subject to an AAER ${ }^{\mathrm{a}}$

\begin{tabular}{|c|c|c|c|c|}
\hline Variables & $\begin{array}{c}\text { (1) } \\
\text { AAER Dummy }\end{array}$ & $\begin{array}{c}\text { (2) } \\
\text { AAER Dummy }\end{array}$ & $\begin{array}{c}\text { (3) } \\
\text { AAER Dummy }\end{array}$ & $\begin{array}{c}\text { (4) } \\
\text { AAER Dummy }\end{array}$ \\
\hline Log Employees & $\begin{array}{c}-0.210^{*} \\
(0.07)\end{array}$ & $\begin{array}{c}-0.238 * * \\
(0.05)\end{array}$ & $\begin{array}{c}-0.269 * * \\
(0.03)\end{array}$ & $\begin{array}{c}-0.222 * \\
(0.09)\end{array}$ \\
\hline F-score 1 & $\begin{array}{c}0.457 * * * \\
(0.00)\end{array}$ & & & $\begin{array}{c}0.457 * * * \\
(0.00)\end{array}$ \\
\hline F-score 2 & & $\begin{array}{c}0.433 * * * \\
(0.00)\end{array}$ & & \\
\hline F-score 3 & & & $\begin{array}{c}0.407^{* * *} \\
(0.00)\end{array}$ & \\
\hline Proximate 100 & $\begin{array}{c}0.347^{* *} \\
(0.04)\end{array}$ & $\begin{array}{c}0.354^{* *} \\
(0.04)\end{array}$ & $\begin{array}{c}0.349^{*} \\
(0.06)\end{array}$ & $\begin{array}{l}0.181 \\
(0.38)\end{array}$ \\
\hline PAC Contribution & $\begin{array}{l}0.001 \\
(0.51)\end{array}$ & $\begin{array}{l}0.001 \\
(0.52)\end{array}$ & $\begin{array}{l}0.001 \\
(0.88)\end{array}$ & \\
\hline Lobbying Exp & & & & $\begin{array}{c}-0.001 * \\
(0.06)\end{array}$ \\
\hline Union & $\begin{array}{l}0.014 \\
(0.31)\end{array}$ & $\begin{array}{l}0.014 \\
(0.30)\end{array}$ & $\begin{array}{l}0.017 \\
(0.24)\end{array}$ & $\begin{array}{l}0.415 \\
(0.85)\end{array}$ \\
\hline Log Analyst Following & $\begin{array}{c}0.287 * * * \\
(0.01)\end{array}$ & $\begin{array}{c}0.286^{* * * *} \\
(0.01)\end{array}$ & $\begin{array}{c}0.282 * * \\
(0.01)\end{array}$ & $\begin{array}{c}0.585 * * * \\
(0.00)\end{array}$ \\
\hline Fortune 500 & $\begin{array}{l}-0.235 \\
(0.69)\end{array}$ & $\begin{array}{l}-0.104 \\
(0.64)\end{array}$ & $\begin{array}{l}-0.117 \\
(0.60)\end{array}$ & $\begin{array}{l}-0.212 \\
(0.45)\end{array}$ \\
\hline ROA & $\begin{array}{l}0.094 \\
(0.71)\end{array}$ & $\begin{array}{l}-0.014 \\
(0.96)\end{array}$ & $\begin{array}{l}0.163 \\
(0.58)\end{array}$ & $\begin{array}{l}0.129 \\
(0.71)\end{array}$ \\
\hline Big 4 & $\begin{array}{c}-0.589 * * * \\
(0.01)\end{array}$ & $\begin{array}{c}-0.551 * * \\
(0.01)\end{array}$ & $\begin{array}{c}-0.555^{* *} \\
(0.02)\end{array}$ & $\begin{array}{l}-0.256 \\
(0.46)\end{array}$ \\
\hline Market-to-Book & $\begin{array}{c}0.027 * * * \\
(0.00)\end{array}$ & $\begin{array}{c}0.028 * * * \\
(0.00)\end{array}$ & $\begin{array}{c}0.022 * * \\
(0.03)\end{array}$ & $\begin{array}{l}0.016 \\
(0.19)\end{array}$ \\
\hline Leverage & $\begin{array}{l}0.082 \\
(0.80)\end{array}$ & $\begin{array}{l}0.080 \\
(0.80)\end{array}$ & $\begin{array}{l}0.064 \\
(0.85)\end{array}$ & $\begin{array}{l}0.175 \\
(0.65)\end{array}$ \\
\hline Log Firm Age & $\begin{array}{c}-0.187 * * \\
(0.03)\end{array}$ & $\begin{array}{c}-0.180 * * \\
(0.04)\end{array}$ & $\begin{array}{c}-0.214 * * \\
(0.03)\end{array}$ & $\begin{array}{l}0.020 \\
(0.85)\end{array}$ \\
\hline Log Assets & $\begin{array}{c}0.364 * * * \\
(0.00)\end{array}$ & $\begin{array}{c}0.382 * * * \\
(0.00)\end{array}$ & $\begin{array}{c}0.417 * * * \\
(0.00)\end{array}$ & $\begin{array}{c}0.295 * * * \\
(0.00)\end{array}$ \\
\hline Constant & $\begin{array}{c}-10.565^{* * *} \\
(0.00)\end{array}$ & $\begin{array}{c}-10.649 * * * \\
(0.00)\end{array}$ & $\begin{array}{c}-10.686^{* * *} \\
(0.00)\end{array}$ & $\begin{array}{c}-11.403 * * * \\
(0.00)\end{array}$ \\
\hline SEC Chairman Dummies & Yes & Yes & Yes & Yes \\
\hline U.S. President Dummies & Yes & Yes & Yes & Yes \\
\hline Industry Dummies & Yes & Yes & Yes & Yes \\
\hline Year Dummies & Yes & Yes & Yes & Yes \\
\hline Clustered by & Firm & Firm & Firm & Firm \\
\hline Observations & 79,597 & 78,598 & 72,494 & 38,419 \\
\hline Pseudo R-squared & 0.123 & 0.125 & 0.136 & 0.152 \\
\hline
\end{tabular}

Notes to Table 3, Panel A:

${ }^{\text {a }}$ The dependent variable for all the models presented here is an indicator variable that is equal to one in the years a firm has been convicted for allegedly misstating its financial statements as reported in Accounting and Auditing Enforcement Releases, and zero otherwise for the period 1982-2012. The results reported are from a logistic regression estimation. The models differ in the variables included and sample composition. In particular, Model 1,2 and 3 differ in the F-score control variable. Model 4 includes a control variable for a firm's lobbying efforts instead of a firm's PAC contributions. As the data on lobbying expenditures is only available from 1998 onwards, this model is limited to the period 1998-2012. $P$-values are displayed in parentheses below the coefficient estimate. $* * *, * * *$ represent significance at the 10,5 , and 1 percent level (two-tailed), respectively; variables are winsorized at $1 \%$ and $99 \%$ levels. See Appendix B for variable definitions. 


\section{Panel B: Propensity score estimation using probit regression and covariate balance}

between the matched pairs ${ }^{\mathrm{b}}$

\begin{tabular}{|c|c|c|c|c|}
\hline Variables & $\begin{array}{c}(1) \\
\text { Top Quartile Number of } \\
\text { Employees } \\
\end{array}$ & $\begin{array}{c}\text { (2) } \\
\text { Mean top quartile large } \\
\text { employers }\end{array}$ & $\begin{array}{c}\text { (3) } \\
\text { Mean matched non-top } \\
\text { quartile employers }\end{array}$ & $\begin{array}{c}(4) \\
\text { Mean Difference } \\
(2)-(3) \\
\end{array}$ \\
\hline F-score 1 & $\begin{array}{c}0.091 * * * \\
(0.00)\end{array}$ & 1.073 & 1.083 & $\begin{array}{l}-0.010 \\
(0.35)\end{array}$ \\
\hline Proximate 100 & $\begin{array}{c}-0.107 * * * \\
(0.00)\end{array}$ & 0.283 & 0.294 & $\begin{array}{l}-0.011 \\
(0.12)\end{array}$ \\
\hline PAC Contribution & $\begin{array}{c}0.001 * * * \\
(0.00)\end{array}$ & 8.606 & 8.945 & $\begin{array}{l}-0.339 \\
(0.42)\end{array}$ \\
\hline Union & $\begin{array}{c}0.961 * * * \\
(0.00)\end{array}$ & 0.122 & 0.123 & $\begin{array}{l}-0.001 \\
(0.41)\end{array}$ \\
\hline Log Analyst Following & $\begin{array}{c}-0.058^{* * *} \\
(0.00)\end{array}$ & 1.504 & 1.518 & $\begin{array}{l}-0.014 \\
(0.31)\end{array}$ \\
\hline Fortune 500 & $\begin{array}{c}0.464 * * * \\
(0.00)\end{array}$ & 0.031 & 0.033 & $\begin{array}{l}-0.002 \\
(0.66)\end{array}$ \\
\hline ROA & $\begin{array}{c}0.609 * * * \\
(0.00)\end{array}$ & 0.008 & 0.007 & $\begin{array}{l}0.001 \\
(0.50)\end{array}$ \\
\hline Big 4 & $\begin{array}{c}-0.112 * * * \\
(0.00)\end{array}$ & 0.906 & 0.899 & $\begin{array}{l}0.007 \\
(0.14)\end{array}$ \\
\hline Market-to-Book & $\begin{array}{l}0.001 \\
(0.90)\end{array}$ & 2.507 & 2.726 & $\begin{array}{l}-0.219 \\
(0.83)\end{array}$ \\
\hline Leverage & $\begin{array}{c}-0.088 * * \\
(0.02)\end{array}$ & 0.224 & 0.224 & $\begin{array}{l}0.000 \\
(0.85)\end{array}$ \\
\hline Log Firm Age & $\begin{array}{c}0.252 * * * \\
(0.00)\end{array}$ & 2.518 & 2.525 & $\begin{array}{l}-0.007 \\
(0.56)\end{array}$ \\
\hline Log Assets & $\begin{array}{c}1.123 * * * \\
(0.00)\end{array}$ & 5.931 & 5.934 & $\begin{array}{l}-0.003 \\
(0.87)\end{array}$ \\
\hline Constant & $\begin{array}{c}-7.477 * * * \\
(0.00)\end{array}$ & & & \\
\hline SEC Chairman Dummies & Yes & & & \\
\hline U.S. President Dummies & Yes & & & \\
\hline Industry Dummies & Yes & & & \\
\hline Year Dummies & Yes & & & \\
\hline Observations & 92,531 & 8,248 & 8,248 & \\
\hline Pseudo R-squared & 0.647 & & & \\
\hline
\end{tabular}

Notes to Table 3, Panel B:

${ }^{b}$ Column 1 presents the propensity score estimation and columns 2-4 the covariate balance between the matched pairs. The dependent variable for model 1 is an indicator variable that is equal to one if a firm's log number of employees is in the top quartile of log number of employees, and zero otherwise for the period 1982-2012. The results reported are from a Probit regression estimation and are used to calculate the propensity scores. Columns 2-4 report the average values of the variables used in my matching procedure after matching and the average difference in these variables of top quartile employers and the matched non-top quartile employers. Propensity scores for matching are obtained from the probit model in column 1. Each top quartile firm observation is matched to a non-top quartile firm observation within the same year, industry, SEC Chairman as well as U.S. President year, using propensity score estimation, without replacement. To ensure the smallest propensity-score distance between the treatment and control firms, I apply the caliper matching estimator. To match top quartile employers to non-top quartile employers, I use a caliper of 0.0005 . $P$-values are displayed in parentheses below the coefficient estimate. $*, * *, * * *$ represent significance at the 10, 5 , and 1 percent level (two-tailed), respectively; variables are winsorized at $1 \%$ and $99 \%$ levels. See Appendix B for variable definitions. 


\section{Panel C: Average Treatment Effect ${ }^{\mathrm{c}}$}

\begin{tabular}{|c|c|c|}
\hline Variables & $\mathbf{N}$ & AAER Dummy \\
\hline Mean Top Quartile Large Employers & 8,248 & 0.005 \\
\hline Mean Matched Non-Top Quartile Large Employers & 8,248 & 0.013 \\
\hline Mean Difference & & $-0.008 * * *$ \\
\hline
\end{tabular}


Table 4: Test of hypothesis 2

Panel A: Logistic regression estimation of the probability of being subject to an AAER in an election year (if headquartered in highly contested states) ${ }^{\mathbf{a}}$

\begin{tabular}{|c|c|c|}
\hline \multirow{2}{*}{ Variables } & \multirow{2}{*}{$\begin{array}{c}\text { (1) } \\
\text { AAER Dummy }\end{array}$} & \multirow{2}{*}{$\begin{array}{c}\text { (2) } \\
\text { AAER Dummy }\end{array}$} \\
\hline & & \\
\hline \multirow[t]{2}{*}{ Log Employees } & $-0.222 *$ & $-0.209^{*}$ \\
\hline & $(0.05)$ & $(0.07)$ \\
\hline \multirow[t]{2}{*}{ Election Year } & $-1.016 * *$ & $-0.853 * *$ \\
\hline & $(0.01)$ & $(0.04)$ \\
\hline \multirow{2}{*}{ Log Employees * Election Year } & 0.052 & 0.016 \\
\hline & $(0.28)$ & $(0.75)$ \\
\hline \multirow[t]{2}{*}{ Important State } & & -0.320 \\
\hline & & $(0.29)$ \\
\hline \multirow[t]{2}{*}{ Important State * Log Employees } & & 0.076 \\
\hline & & $(0.68)$ \\
\hline \multirow[t]{2}{*}{ Important State * Election Year } & & 0.393 \\
\hline & & $(0.34)$ \\
\hline \multirow[t]{2}{*}{ Log Employees * Election Year * Important State } & & $-0.380 *$ \\
\hline & & $(0.08)$ \\
\hline \multirow[t]{2}{*}{ F-score 1} & $0.425 * * *$ & $0.460 * * *$ \\
\hline & $(0.00)$ & $(0.00)$ \\
\hline \multirow[t]{2}{*}{ Proximate 100} & $0.341 * *$ & $0.332 *$ \\
\hline & $(0.04)$ & $(0.05)$ \\
\hline \multirow[t]{2}{*}{ PAC Contribution } & 0.001 & 0.001 \\
\hline & $(0.43)$ & $(0.50)$ \\
\hline \multirow[t]{2}{*}{ Union } & 0.015 & 0.014 \\
\hline & $(0.29)$ & $(0.31)$ \\
\hline \multirow[t]{2}{*}{ Log Analyst Following } & $0.246 * *$ & $0.286 * * *$ \\
\hline & $(0.02)$ & $(0.01)$ \\
\hline \multirow[t]{2}{*}{ Fortune 500} & -0.103 & -0.091 \\
\hline & $(0.64)$ & $(0.68)$ \\
\hline \multirow[t]{2}{*}{ ROA } & -0.188 & -0.084 \\
\hline & $(0.46)$ & $(0.74)$ \\
\hline \multirow[t]{2}{*}{ Big 4} & $-0.625^{* * *}$ & $-0.589 * * *$ \\
\hline & $(0.00)$ & $(0.01)$ \\
\hline \multirow[t]{2}{*}{ Market-to-Book } & $0.021^{* *}$ & $0.027 * * *$ \\
\hline & $(0.02)$ & $(0.00)$ \\
\hline \multirow[t]{2}{*}{ Leverage } & 0.017 & 0.094 \\
\hline & $(0.96)$ & $(0.77)$ \\
\hline \multirow[t]{2}{*}{ Log Firm Age } & $-0.169 *$ & $-0.184 * *$ \\
\hline & $(0.05)$ & $(0.03)$ \\
\hline \multirow[t]{2}{*}{ Log Assets } & $0.392 * * *$ & $0.360 * * *$ \\
\hline & $(0.00)$ & $(0.00)$ \\
\hline \multirow[t]{2}{*}{ Constant } & $-10.569 * * *$ & $-10.522 * * *$ \\
\hline & $(0.00)$ & $(0.00)$ \\
\hline SEC Chairman Dummies & Yes & Yes \\
\hline U.S. President Dummies & Yes & Yes \\
\hline Industry Dummies & Yes & Yes \\
\hline Year Dummies & Yes & Yes \\
\hline Clustered by & Firm & Firm \\
\hline Observations & 79,597 & 79,597 \\
\hline Pseudo R-squared & 0.119 & 0.123 \\
\hline
\end{tabular}


particular, Model 1 provides the results for testing H2a and Model 2 provides the results for testing H2b. $P$-values are displayed in parentheses below the coefficient estimate. ${ }^{*}, * *, * * *$ represent significance at the 10,5 , and 1 percent level (two-tailed), respectively; variables are winsorized at $1 \%$ and $99 \%$ levels. See Appendix B for variable definitions.

\section{Panel B: Logistic regression estimation of the probability of being subject to an AAER if based in a district with high unemployment rate (and a congressman that serves on a committee overseeing the SEC) ${ }^{b}$}

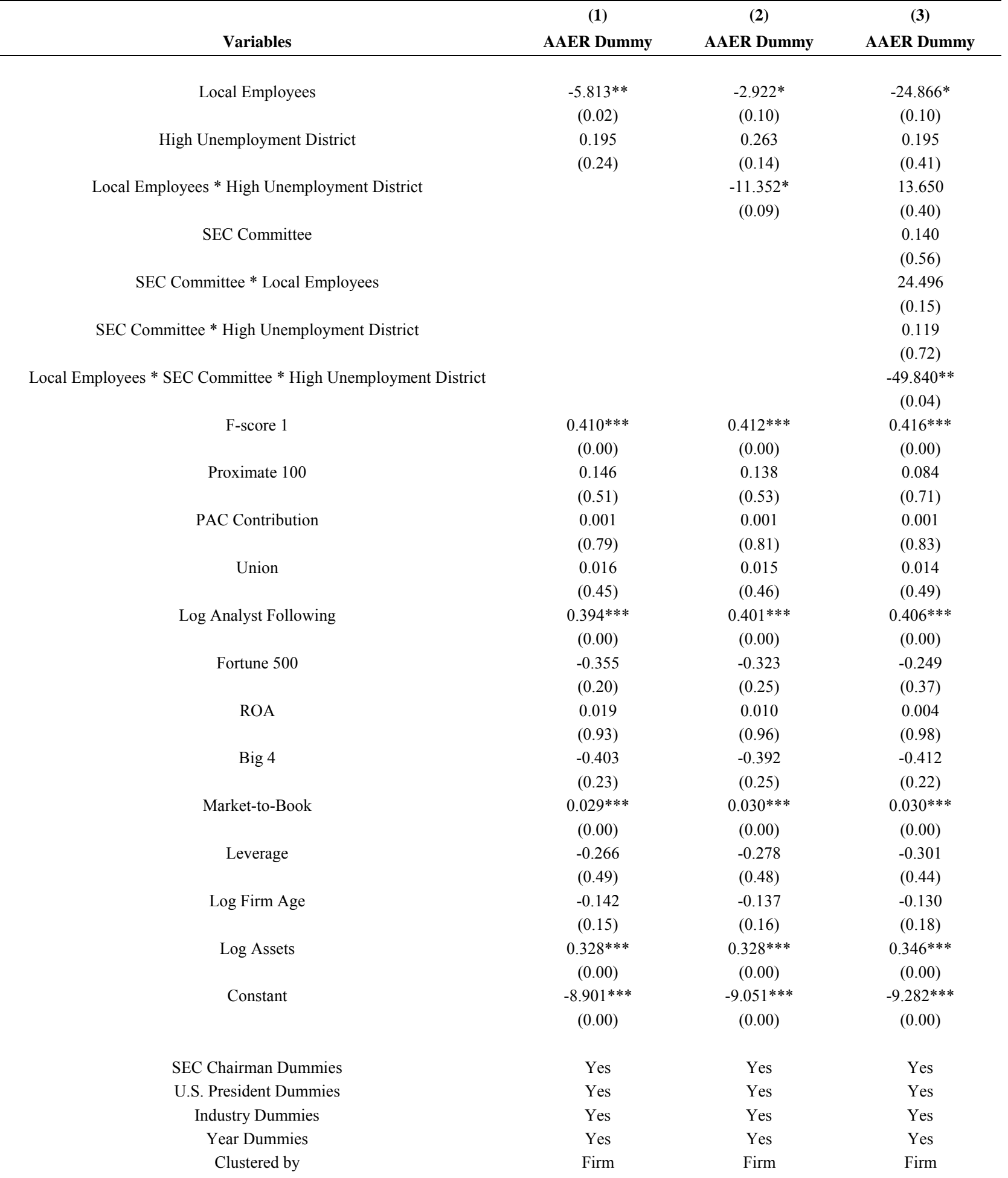




\begin{abstract}
Observations
38,907

38,907

38,907

Pseudo R-squared

0.134

0.136

0.141

Notes to Table 4, Panel B:

${ }^{\mathrm{b}}$ The dependent variable for all the models presented here is an indicator variable that is equal to one in the years a firm has been convicted for allegedly misstating its financial statements as reported in Accounting and Auditing Enforcement Releases, and zero otherwise for the period 1994-2008. The results reported are from a logistic regression estimation. The models differ in the variables included. In particular, Model 1 uses a firm's adjusted (i.e., based on the data obtained from Garcia and Norli (2012) who count the occurrence of the headquarter state in a firm's 10$\mathrm{K}$ relative to all other states) number of employees relative to the total workforce in a district and includes the unemployment rate per district for the period 1994 to 2008. Model 2 provides the results for testing H2c and does not include the unemployment rate per district. Instead, it includes an indicator variable for districts with a higher unemployment rate than the districts in the same state. Model 3 provides the results for testing $\mathrm{H} 2 \mathrm{~d}$ and includes, next to the variables included in Model 2, an indicator variable for congressmen that serve on committees overseeing the SEC. $P$-values are displayed in parentheses below the coefficient estimate. ${ }^{*}, * *, * *$ represent significance at the 10,5 , and 1 percent level (twotailed), respectively; variables are winsorized at $1 \%$ and $99 \%$ levels. See Appendix B for variable definitions.
\end{abstract}

\title{
Table 5: OLS and logistic regression estimation of accounting quality for large employers ${ }^{\mathrm{a}}$
}

\begin{tabular}{|c|c|c|c|c|c|c|}
\hline Variables & $\begin{array}{c}\text { (1) } \\
\text { F-score 1 } \\
\end{array}$ & $\begin{array}{c}(2) \\
\text { F-score } 2 \\
\end{array}$ & $\begin{array}{c}\text { (3) } \\
\text { F-score } 3 \\
\end{array}$ & $\begin{array}{l}\text { (4) } \\
\text { Mod. Jones } \\
\text { Dis. Acc. } \\
\end{array}$ & $\begin{array}{c}\text { (5) } \\
\text { DD Dis. Acc. }\end{array}$ & $\begin{array}{c}\text { (6) } \\
\text { Restatement } \\
\end{array}$ \\
\hline Log Employees & $\begin{array}{l}0.028 * * * \\
(0.00)\end{array}$ & $\begin{array}{c}0.021 * * \\
(0.02)\end{array}$ & $\begin{array}{c}0.020^{* *} \\
(0.04)\end{array}$ & $\begin{array}{c}0.002 * * * \\
(0.00)\end{array}$ & $\begin{array}{c}0.002 * * * \\
(0.00)\end{array}$ & $\begin{array}{l}-0.041 \\
(0.44)\end{array}$ \\
\hline ROA & $\begin{array}{l}0.238^{* * * *} \\
(0.00)\end{array}$ & $\begin{array}{c}0.187 * * * \\
(0.00)\end{array}$ & $\begin{array}{c}0.224 * * * \\
(0.00)\end{array}$ & $\begin{array}{c}-0.041 * * * \\
(0.00)\end{array}$ & $\begin{array}{c}-0.035^{* * *} \\
(0.00)\end{array}$ & $\begin{array}{c}-1.090^{* * *} \\
(0.00)\end{array}$ \\
\hline Big 4 & $\begin{array}{c}-0.097 * * * \\
(0.00)\end{array}$ & $\begin{array}{c}-0.092 * * * \\
(0.00)\end{array}$ & $\begin{array}{c}-0.105^{* * *} \\
(0.00)\end{array}$ & $\begin{array}{c}-0.004 * * * \\
(0.00)\end{array}$ & $\begin{array}{c}-0.005 * * * \\
(0.00)\end{array}$ & $\begin{array}{l}-0.128 \\
(0.17)\end{array}$ \\
\hline Market-to-Book & $\begin{array}{c}0.007 * * * \\
(0.00)\end{array}$ & $\begin{array}{l}0.006^{* * * *} \\
(0.00)\end{array}$ & $\begin{array}{c}0.008 * * * \\
(0.00)\end{array}$ & $\begin{array}{l}0.000^{* * *} \\
(0.00)\end{array}$ & $\begin{array}{c}0.001 * * * \\
(0.00)\end{array}$ & $\begin{array}{l}-0.111 \\
(0.12)\end{array}$ \\
\hline Leverage & $\begin{array}{c}0.352 * * * \\
(0.00)\end{array}$ & $\begin{array}{c}0.412 * * * \\
(0.00)\end{array}$ & $\begin{array}{c}0.390 * * * \\
(0.00)\end{array}$ & $\begin{array}{c}-0.006^{* * *} \\
(0.00)\end{array}$ & $\begin{array}{c}0.016^{* * *} \\
(0.00)\end{array}$ & $\begin{array}{c}.177 \\
(0.27)\end{array}$ \\
\hline Log Firm Age & $\begin{array}{c}-0.084 * * * \\
(0.00)\end{array}$ & $\begin{array}{c}-0.089 * * * \\
(0.00)\end{array}$ & $\begin{array}{c}-0.070 * * * \\
(0.00)\end{array}$ & $\begin{array}{c}-0.003 * * * \\
(0.00)\end{array}$ & $\begin{array}{c}-0.005^{* * *} \\
(0.00)\end{array}$ & $\begin{array}{l}-0.003 \\
(0.95)\end{array}$ \\
\hline Log Assets & $\begin{array}{c}0.016 * * * \\
(0.00)\end{array}$ & $\begin{array}{c}0.023 * * * \\
(0.00)\end{array}$ & $\begin{array}{c}0.021 * * * \\
(0.00)\end{array}$ & $\begin{array}{c}-0.007 * * * \\
(0.00)\end{array}$ & $\begin{array}{c}-0.005^{* * *} \\
(0.00)\end{array}$ & $\begin{array}{c}0.184^{* * *} \\
(0.00)\end{array}$ \\
\hline Constant & $\begin{array}{c}0.971 * * * \\
(0.00)\end{array}$ & $\begin{array}{c}0.306^{* * *} \\
(0.00)\end{array}$ & $\begin{array}{c}1.117 * * * \\
(0.01)\end{array}$ & $\begin{array}{c}0.126 * * * \\
(0.00)\end{array}$ & $\begin{array}{c}0.092 * * * \\
(0.00)\end{array}$ & $\begin{array}{c}-3.723 * * * \\
(0.00)\end{array}$ \\
\hline Industry Dummies & Yes & Yes & Yes & Yes & Yes & Yes \\
\hline Year Dummies & Yes & Yes & Yes & Yes & Yes & Yes \\
\hline Clustered by & Firm & Firm & Firm & Firm & Firm & Firm \\
\hline Observations & 93,207 & 91,953 & 85,215 & 91,870 & 72,954 & 37,907 \\
\hline $\begin{array}{c}\text { Adj. R-squared / } \\
\text { Pseudo R-squared }\end{array}$ & 0.165 & 0.175 & 0.179 & 0.177 & 0.134 & 0.084 \\
\hline
\end{tabular}

Notes to Table 5:

${ }^{a}$ The dependent variable for all the models presented here is a different proxy for a firm's accounting quality for the period 1982-2012 (Model 15) and 1997-2006 (Model 6). The first three models use all three types of F-scores as defined by Dechow et al. (2011). The dependent variables in Model 4 and Model 5, respectively, are absolute discretionary accruals estimated from a modified Jones model as in Dechow et al. (2011) and estimated according to Dechow and Dichev (2002), respectively. The dependent variable in Model 6 is an indicator variable that is one in the years a restatement has been released by firms, and zero otherwise. The results reported for Models 1-5 are from an ordinary least squares regression estimation and for Model 6 from a logistic regression estimation. $P$-values are displayed in parentheses below the coefficient estimate. $*, * *, * * *$ represent significance at the 10,5 , and 1 percent level (two-tailed), respectively; variables are winsorized at $1 \%$ and $99 \%$ levels. See Appendix B for variable definitions. 


\section{Table 6: Tobit and logistic regression estimation of the number of comment letters and the probability of receiving a comment letter ${ }^{\mathrm{a}}$}

(1)

Variables

Comment Letter Dummy

(2)

Number Comment Letters

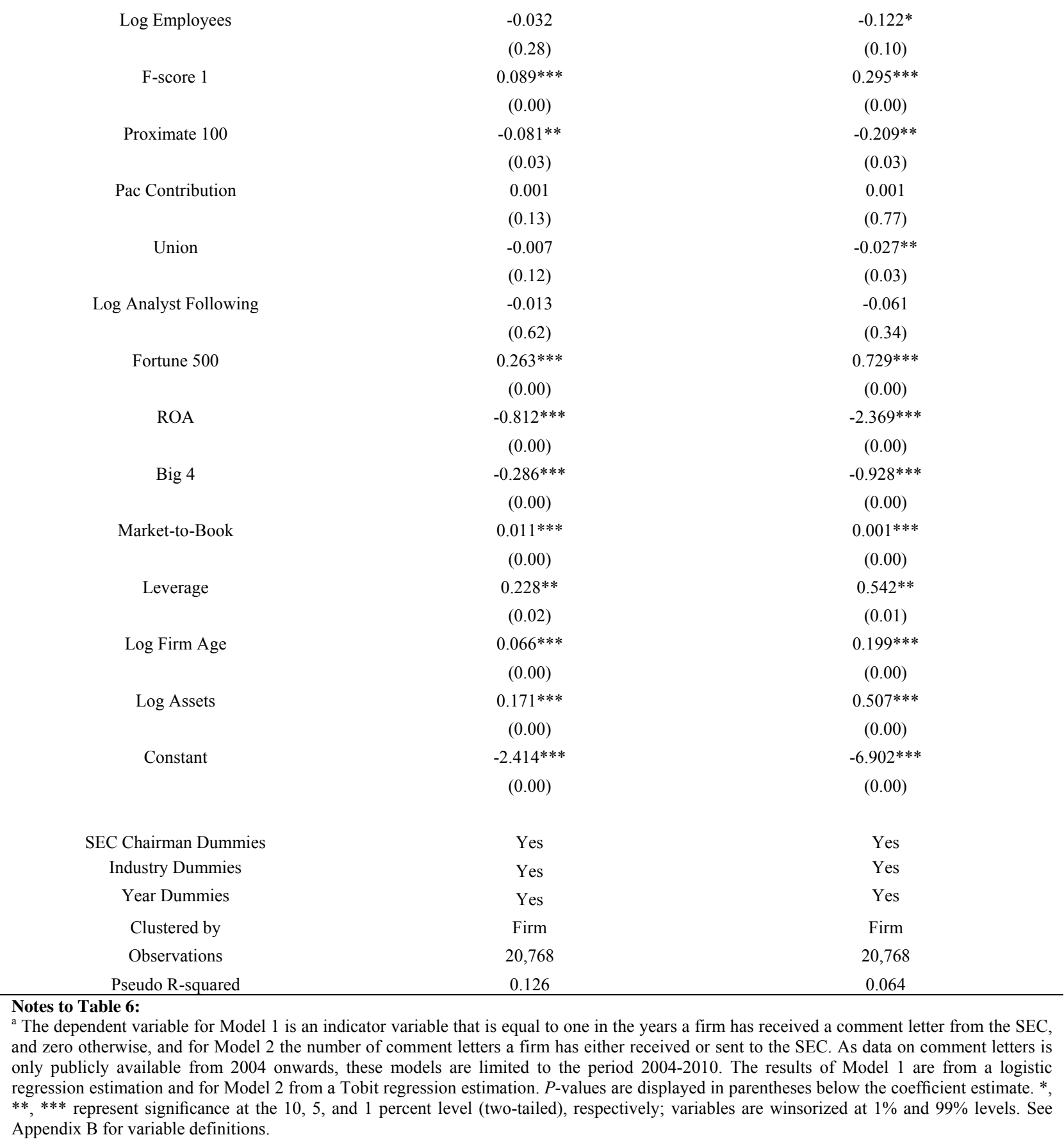


Table 7: Sensitivity tests

Class Action Lawsuits Sample and U.S. vs. Non-U.S. Employment

Variables

Log Employees

U.S. Log Employees

Non-U.S. Log Employees

F-score 1

F-score 2

F-score 3

Proximate 100

PAC Contribution

Lobbying Exp

Union

Log Analyst Following

Fortune 500

ROA

Big 4

Market-to-Book

Leverage

Log Firm Age

Log Assets

Constant

SEC Chairman Dummies

U.S. President Dummies

Industry Dummies

Year Dummies

Clustered by

Observations

Pseudo R-squared
(1)

AAER Dummy

(2)

AAER Dummy

$-0.265^{*}$

(0.10)

(0.07)

$\begin{array}{cc} & -0.366^{*} \\ & (0.08) \\ & 0.003 \\ & (0.82) \\ 0.300^{* * *} & 0.331 * * * \\ (0.00) & (0.00)\end{array}$

(2)

AAER Dummy
0.177

$(0.50)$

.001

(0.91)

0.014

(0.55)

0.195

(0.19)

$-0.227$

$(0.45)$

$0.784 *$

(0.09)

0.119

(0.77)

0.001

$(0.51)$

0.764 **

(0.03)

0.146

(0.28)

$0.248 * *$

(0.04)

$-5.929 * * *$

(0.00)

$-10.565^{* * *}$

(0.00)

Yes

Yes

Yes

Yes

Firm

79,597
Yes

Yes

Yes

Yes

Firm

5,420

0.111

0.123

0.023

(0.95)

0.002

(0.53)

$-0.005$

(0.17)

$0.668 * *$

(0.02)

$-0.315$

(0.60)

$-0.127$

(0.74)

$-0.012$

(0.98)

$0.003 * *$

(0.02)

0.853

(0.45)

0.194

(0.44)

0.273

(0.17)

$-7.118^{* * *}$

(0.00)

Yes

Yes

Yes

Yes

Firm

5,018

0.152

Notes to Table 7:

${ }^{a}$ The dependent variable for all the models presented here is an indicator variable that is equal to one in the years a firm has been convicted for allegedly misstating its financial statements as reported in Accounting and Auditing Enforcement Releases, and zero otherwise for the period 1982-2012. The results reported are from a logistic regression estimation. Model 1 is the same as Model 1 in Table 3, Panel A. Model 2 uses a sample of firms subject to class action lawsuits for the period 1996-2012. Model 3 splits a firm's employees into U.S. versus non-U.S. employees for a subset of firms with available data in Compustat Segments. $P$-values are displayed in parentheses below the coefficient estimate. $*, * *, * * *$ represent significance at the 10,5 , and 1 percent level (two-tailed), respectively; variables are winsorized at 1\% and $99 \%$ levels. See Appendix B for variable definitions. 